\title{
ПРАВООТНОШЕНИЯ НА МЕЖДУНАРОДНОМ ФИНАНСОВОМ РЫНКЕ
}

\begin{abstract}
Аннотация. В статье рассматриваются особенности правового регулирования международных частных финансовых отношений: проанализированы методы, субъекты и источники регулирования; определена роль международного частного права; выделены основные виды сделок, заключаемых на международном финансовом рынке. Автор выделяет три уровня регулирования отношений на международном финансовом рынке: макро-регулирование, функциональное регулирование и саморегулирование. $B$ статье выделяется общая черта международных частных финансовых правоотношений-присутствие иностранного элемента, который может проявляться в субъектном составе, в объекте правоотношения, либо в юридическом факте, с которым связано возникновение, изменение или прекращение данного правоотношения. Автор статьи предлагает обобщить операщии, осуществляемые на международном рынке капиталов, в три основных группы: трансграничный выпуск акиий, международных облигаиий и договоры международного (синдииированного) займа. В статье использованы системный, комплексный, исторический, диалектический сравнительно-правовой научные методы. Подробно проанализировань иностранные источники. Автором предпринимается попытка проанализировать частно-правовые отномения на международном финансовом рынке, а также особенности их правового регулирования. Автор предлагает рассматривать правовое регулирование отномений на международном финансовом рынке с трех позищий: с позищи макро-регулирования, функционального регулирования и саморегулирования. Макро-регулирование затрагивает международный финансовый рынок в целом и осуществляется МВФ и Форумом финансовой стабильности, в то время как функииональное и саморегулирование осущесттвляется в различных секторах: первое затрагивает рынок банковских услуг (БМР), иенных бумаг (ИОСКО) и страхования (ИАИС), второе - рынок синдицированных кредитов (ЛМА), иенных бумаг (МАРК) и деривативов (ИСДА). Особую роль в регулировании международных финансовых отношений играет международное частное право и деятельность УНИДРУА. Общая черта международных частных финансовых правоотношений заключается в том, что они возникают на основании трансграничных сделок, основная черта которых заключается в иностранном элементе, который может проявляться в субъектном составе, в объекте правоотношения, либо в юридическом факте.
\end{abstract}

Ключевые слова: Правоотношение, финансовые сделки, синдицированные кредиты, международные финансовые организаиии, функциональное регулирование, международный финансовый рынок, саморегулирование, международные облигаџии, ликвидационный неттинг, международные ассоциации.

Abstract: The article concerns specific features of legal regulation of the international financial relations. The author analyzes methods, subjects and sources of regulation, defining the role of international private law. The author also singles out the main types of deals in the international financial market, pointing out three levels of regulation: macro-regulation, functional regulation, self-regulation. The article provides for the common feature of the international private financial legal relations - presence of a foreign element, which may be involved among the subjects of the relations, in the object of the relation, or as a legal fact, concerning formation, alteration or termination of this relation. The author offers to divide the operations in the international capital market into three groups: trans-border issue of shares, international obligations and the treaties for the international syndicated loans. The article involves systemic, complex, historical, dialectic, comparative legal scientific methods. The author also provides a detailed evaluation of the foreign sources. The author attempts to analyze private law relations in the international financial market, as well as specificities of their legal regulation. The author offers to view the legal regulation of the relations in the international financial market from the three standpoints: the position of macro-regulation, functional regulation and self-regulation. Macro-regulation involves an international financial market as a whole, and it is implemented by the IMF and the Financial Stability Forum (FSF), while the functional regulation and self-regulation are implemented in 
different sectors: the former involves the market for the banking services (BIS), securities (IOSCO) and insurance (IAIS), while the latter involves the market for the syndicated credits (LMA), securities (MARC) and derivatives (ISDA) The international private law and the UNIDROIT activities play a special role in the regulation of the international financial relations. The common features of the international private financial legal relations is that they are formed based upon the trans-border deals, and their main feature is a foreign element, which may be present among the subjects of the relations, their object, or a legal fact.

Keywords: Legal relation, financial deals, syndicated credit, international financial organizations, functional regulation, international financial market, self-regulation, international obligation, liquidation netting, international associations.

\section{Методы и источники регулирования отночений на международном финансовом рынке}

од регулированием в данном случае следует понимать любые формы правил поведения субъектов международных частных финансовых отношений. Данные правила могут приниматься и разрабатываться как в рамках отдельных государств, так и на межгосударственном уровне, как носителями государственной власти, так и участниками рынка. Правила и стандарты, разрабатываемые международными организациями в виде рекомендаций, получили в юридической литературе наименование норм «мягкого права» ${ }^{1}$, а стандартные договоры, вырабатываемые участниками рынков, нередко именуются lex mercatoria ${ }^{2}$.

Вопрос правового регулирования международных финансовых отношений - один из наиболее сложных: государства наименее всего

\footnotetext{
${ }^{1}$ См.: Бобов М.О. Новые требования к капиталу банков // Внутренний контроль в кредитной организации. 2012. № 4; Arner D.W., Taylor M.W. The Global Financial Crisis and the Financial Stability Board: Hardening the Soft Law of International Financial Regulation? // University of New South Wales Law Journal. 2009. Vol. 32 (2). P. 488-513; Karmel R.S., Kelly C.R. The Hardening of Soft Law in Securities Regulation // Brooklyn Journal of International Law. 2009. Vol. 34:3. P. 884-951; Möllers T.M.J. Sources of Law in European Securities Regulation - Effective Regulation, Soft Law and Legal Taxonomy from Lamfalussy to de Larosière // European Business Organization Law Review. 2010. Vol. 11 P. 379-407.

${ }^{2}$ См.: Канашевский В.А. Внешнеэкономические сделки: материально-правовое и коллизионное регулирование. М.: Волтерс Клувер, 2010. С. 499-514. Применительно к международным финансовым рынкам В.М. Шумилов, к примеру, предлагает использовать термин lex finanzaria. См.: Шумилов B.M. Международное финансовое право: понятие, предмет, система // Юрист-международник. 2005. № 1. С. 14.
}

склонны приходить к консенсусу в данном вопросе. Несмотря на существование ряда конвенций, разработанных на международном уровне, некоторые из них так и не вступили в силу, другие касаются лишь отдельных вопросов, в то время как остальные морально устарели. Тем не менее, уже несколько десятков лет участники международных финансовых рынков из различных государств заключают многостраничные соглашения, содержащие одни и те же условия, в большинстве случаев типовые, и отражающие сложную структуру возникающих на международном финансовом рынке отношений. Как следствие, отношения на таком рынке в первую очередь регулируются рыночной практикой, обычаями и только потом применимыми нормами национального права ${ }^{3}$.

\footnotetext{
3 Отечественными авторами указывается на значение международных принципов и стандартов в регулировании международных финансовых рынков. Шамраев А.В. Правовое регулирование международных банковских сделок и сделок на международных финансовых рынках. М.: КНОРУС, ЦИПСиР, 2010. С. 7. Швейцарский юрист П. Нобель тоже выделяет отдельную категорию источников - международные стандарты. Автор отмечает, что «международные стандарты - это правила поведения, установки и принципы, которые во всем мире признаны наилучшими и наиболее эффективными в соответствующей области. Международные стандарты всегда носят только рекомендательный характер: они охватывают «передовой опыт» в соответствующей области и не являются нормами позитивного права. В этом смысле их можно назвать установлениями международного «мягкого права» (курсив мой - прим. авт.), которые в силу своей обоснованности постепенно трансформируются в нормы национального права. Эти правила поведения являются необязательными с правовой точки зрения до тех пор, пока они не войдут в международно-правовые договор или национальные нормы. Несоблюдение стандартов может повлечь за собой возникновение рисков и сказаться на уровне процентных ставок государств. Стандарты адресованы в первую очередь парламентам и другим законодательным органам государства, но они могут использоваться и частными институтами». См.: Нобель П. Швейцарское финансовое право и международные стандарты. М., Инфотропик Медиа, 2012. С. 116.
} 


\section{Макро-регулирование}

На национальном финансовом рынке первоочередным регулятором является центральный банк или иная подобная организация, основная функция которой - установление общих правил обращения национальной валюты и осуществление банковского надзора. Существуют также специальные ведомства, устанавливающие правила и осуществляющие надзор в отдельных сегментах финансового рынка: в области рынка ценных бумаг, в области страхового дела. В последнее время все больше государств создают единые органы - так называемые «мега-регуляторы» ${ }^{4}$, к компетенции которых относятся вопросы, связанные с функционированием финансового рынка в целом 5 .

На международном уровне структура органов регулирования в определенной степени отражает подход, присущий национальным правопорядкам. Во главе находится Международный валютный фонд (далее - МВФ), учрежденный на валютно-финансовой конференции Организации объединенных наций в Бреттон-Вудсе, штат Нью-Хэмпшир (США), в 1944 году. К целям МВФ отнесены: содействие развитию международного сотрудничества в валютно-финансовой сфере, расширению и сбалансированному росту международной торговли, стабильности валют, оказание помощи в создании многосторонней системы расчетов по текущим операциям между государствами - членами и другие 6 .

В свою очередь в мировом масштабе еще не было создано единого «мега-регулятора», хотя близко к тому находится Форум финансовой стабильности (далее - Форум $)^{8}$. Форум был создан в 2007 году

\footnotetext{
${ }^{4}$ Баренбойм П.Д. Законопроект о реформе гражданского кодекса игнорирует интересы российских вкладчиков и мировой опыт антикризисной работы на финансовых рынках // Право и экономика. 2010. № 11; Хорошилов С.Д. Банковский сектор стран - членов Совета по сотрудничеству в Персидском заливе // Международные банковские операции. 2006. № 4.

${ }^{5}$ В России план по передаче полномочий мега-регулятору Центральному банку уже реализован.

${ }^{6}$ Статья 1 Статей Соглашения Международного валютного фонда // Официальный сайт МВФ: <http://www.imf.org/external/ pubs/ft/aa/rus/index.pdf $>$.

${ }^{7}$ Mullineux A.W., Murinde V. Handbook of International Banking. Edward Elgar Publishing Limited, 2003. P. 10.

8 УНИДРУА при разработке некоторых своих инструментов прямо ссылается на документы Форума финансовой стабильности. См.: Report on the completion of the intergovernmental negotiations on the Draft Principles, and request for their adoption by the
}

министрами финансов Большой Семерки для того, чтобы координировать на международном уровне работу национальных финансовых органов и органов, устанавливающих международные стандарты на финансовых рынках. Целью Форума является выработка и распространение эффективной политики регулирования и надзора за финансовыми рынками. Секретариат Форума расположен в здании Банка для международных расчетов. Помимо прочего, Форум взаимодействует с МВФ для целей так называемого «раннего предупреждения» ${ }^{9}-$ механизма, разработанного после кризиса 2008 года по инициативе Большой Двадцатки.

Любопытным является свод принципов, разработанных Форумом в 2012 году, касающихся надлежащей практики жилищной ипотеки ${ }^{10}$. Данные принципы были разработаны в ответ на кризис 2008 года и призваны устранить практику непредусмотрительной секьюритизации жилищной ипотеки. Принципы распространяются на договоры займа, обеспеченные ипотекой жилой недвижимости, иным правом на жилую недвижимость и предоставляемые в целях приобретения или сохранения права на жилую недвижимость. Принципы представляют собой список рекомендаций, адресованный законодателям соответствующих государств, и содержат, помимо прочих: принцип эффективной проверки источников дохода заемщика и другой финансовой информации; принцип разумного обслуживания долга; принцип подходящего соотношения кредита и стоимости кредита; принцип эффективного управления обеспечением; принцип рассудительного использования страхования ипотеки и т.п.

Хотя эти принципы направлены на внедрение императивных правил, относящихся, главным образом, к надзору и защите потребителей, а также национальных финансовых систем от рисков, связанных с ипотекой, некоторые из них могут непосред-

Governing Council, as approved by the UNIDRPOIT Committee of governmental experts in March 2013. UNIDROIT 2013. C.D. (92) 6 (a). Р. 3 // Официальный сайт УНИДРУА: <http://www. unidroit.org/english/governments/councildocuments/2013session/ cd92-06a-e.pdf $>$.

${ }^{9}$ The IMF-FSB Early Warning Exercise: Design and Methodological Toolkit // Официальный сайт МВФ: <http://www.imf.org/external/np/pp/eng/2010/090110.pdf>.

${ }^{10}$ FSB Principles for Sound Residential Mortgage Underwriting Practices, 2012 // Официальный сайт Форума финансовой стабильности: <http://www.financialstabilityboard.org/publications/r_111026b.pdf $>$. 
ственно сказаться на имущественных отношениях, если будут приняты во внимание государствами и имплементированы в национальное законодательство. К примеру, принцип подходящего соотношения кредита и стоимости кредита затрагивает вопрос последствий изменения валютного курса: данный принцип предполагает, что в кредитном договоре, предметом которого выступает валюта, необходимо предусматривать разумные последствия изменения валютного курса, которое является неблагоприятным для заемщика, то есть принимать во внимание ответственность за неисполнение обязательств. Такие разумные последствия могут проявляться, в частности, в том, что в случае резкого изменения валютного курса и в случае неплатежа со стороны заемщика, последнему должен быть предоставлен разумный срок для погашения кредита.

В рамках Форума был разработан еще один документ, имеющий значение для международного финансового рынка - свод правил, касающихся Основных принципов эффективных режимов для финансовых институтов ${ }^{11}$. Как и Принципы надлежащей практики жилищной ипотеки, данный документ был разработан в ответ на кризис 2008 года. Эффективные режимы для финансовых институтов - это по существу особая процедура наблюдения, инициируемая государством в отношении системообразующих финансовых организаций в период до появления признаков банкротства. Основные принципы эффективных режимов для финансовых институтов касаются холдинговых компаний, филиалов иностранных компаний, финансовых систем ${ }^{12}$. Данный свод правил распространяется также и на соглашения о взаимозачете, ликвидационный неттинг

\footnotetext{
${ }^{11}$ Key Attributes of Effective Resolutions Regimes for Financial Institutions. Financial Stability Board, 2011 // Официальный сайт Форума финансовой стабильности: $<\mathrm{http}$ :/www.financialstabilityboard.org/publications/r_111104cc.pdf $>$.

${ }^{12}$ В тексте документа они совместно именуются (дословно) «инфраструктурой финансового рынка», определяемой в качестве «многосторонней системы финансовых институтов, включающей оператора системы, функционирующего для целей записи, клиринга, взаимозачета платежей, ценных бумаг, деривативов и других финансовых сделок». Данное определение было разработано совместно Комитетом по платежным системам Банка для международных расчетов и Международной организацией комиссий по ценным бумагам (см.: CPSS-IOSCO - Consultative report on Principles for financial market infrastructures, 2011 // Официальный сайт Банка для международных расчетов: $<$ http://www.bis.org/publ/cpss94.pdf $>$ ).
}

и обеспечительные сделки: призывая государства предоставлять судебную защиту таким сделкам, авторы указанных принципов предоставляют уполномоченным органам право «приостанавливать» действие данных сделок на определенный срок ${ }^{13}$. В частности, предусматривается право регулирующего органа приостанавливать положения «стандартной рыночной документации для финансовых контрактов», касающихся досрочного исполнения, прекращения и других подобных обязательств ${ }^{14}$.

\section{«Функциональное» регулирование}

На международном уровне действуют специальные органы, задачей которых является регулирование отдельных сегментов международного финансового рынка - так называемые «функциональные регуляторы» ${ }^{15}$. Одним из основных «функциональных регуляторов» в сфере международного банковского дела является Банк для международных расчетов (далее - БМР), а точнее, созданный в рамках него Базельский комитет по банковскому надзору. Базельский комитет появился в ответ на банкротство банка «Херштатт» с целью укрепления глобального регулирования в отношении достаточности капитала и ликвидности, более устойчивого банковского сектора ${ }^{16}$. В рамках БМР существует Комитет по платежным системам, который занимается вопросами надзора за платежными системами, а также разработкой принципов их функционирования и активно взаимодействует с Международной организацией комиссий по ценным бумагам (далее - ИОСКО $)^{17}$. БМР выработал ряд документов, каса-

\footnotetext{
${ }^{13}$ УНИДРУА инкорпорировал данный подход в свод принципов, посвященных условиям о ликвидационном неттинге, принятый в мае 2013 года, о котором будет упомянуто ниже.

${ }^{14}$ Речь идет главным образом о так называемом Генеральном соглашении Международной ассоциации свопов и деривативов, широко используемом на международном финансовом рынке. См.: ISDA Master Agreement // Официальный сайт Международной ассоциации свопов и деривативов: <http:// www.isda.org/publications/isdamasteragrmnt.aspx $>$.

${ }^{15}$ Scott H.S. Op. cit. P. 8.

${ }^{16}$ Повышение устойчивости банковского сектора. Консультативный материал. Базельский комитет по банковскому надзору. 2009 // Официальный сайт Банка России: <http:/www.cbr.ru/ today $/ \mathrm{ms} / \mathrm{bn} / 1 . \mathrm{pdf}>$.

${ }^{17}$ См.: Recommendations for securities settlement systems. CPSSIOSCO, 2010 // Официальный сайт БMP: <http://www.bis.org/
} 
ющихся платежных и расчетных систем. К примеру, в 2001 году были приняты Ключевые принципы для системно-значимых платежных систем, а также (совместно с ИОСКО) Рекомендации для систем расчета по ценным бумагам ${ }^{18}$.

ИОСКО отвечает за унификацию регулирования на рынке ценных бумаг. Данная организация была основана в 1983 году19, члены ИОСКО регулируют более $95 \%$ рынков ценных бумаг по всему миру из более ста юрисдикций ${ }^{20}$. В отличие от Базельского комитета интерес ИОСКО сосредоточен на рынках капитала: основным документом, разработанным ИОСКО, являются «Цели и принципы регулирования рынка ценных бумаг» ${ }^{21}$. Данный документ устанавливает три основных цели - защита инвесторов, обеспечение честности, эффективности и прозрачности рынков, а также снижение системного риска - и тридцать принципов, составляющих восемь групп: принципы, адресованные регулятору; принципы саморегулирования; принципы приведения в исполнение регулирования рынка ценных бумаг; принципы кооперации и регулирования; принципы, адресованные эмитентам; принципы, адресованные коллективным инвестиционным схемам; принципы, адресованные посредникам на рынке ценных бумаг; принципы вторичного рынка. Например, устанавливается принцип равенства держателей ценных бумаг. В целом, принципы устанавливают правила поведения на рынке, такие как прозрачность, раскрытие информации, требования достаточности капитала к посредникам, запрет манипуляцией рынка и другие. Данный документ закрепляет широкие полномочия

publ/cpss46.pdf>; Consultative report on Principles for financial market infrastructures. CPSS-IOSCO, 2011 // Официальный сайт БMP: <http://www.bis.org/publ/cpss94.pdf>

${ }^{18}$ См. подробнее: Шамраев А.В. Указ. соч. С. 41. Как отмечает А.В. Шамраев, оба документа входят в число международных стандартов, на соответствие которым Мировым банком и МВФ проводится оценка законодательства отдельных стран, регулирующего финансовый сектор, в рамках Программы оценки финансового сектора (Financial Sector Assessment Program // Официальный сайт МВФ < http://www.imf.org/external/NP/ fsap/fsap.aspx $>$ ).

${ }^{19}$ Примечательно, что ИОСКО возникло на основе Межамериканской региональной ассоциации, возникшей в 1974 году.

${ }^{20}$ Официальный сайт ИОСКО: <http:/www.iosco.org/about/ index.cfm?section=background $>$.

${ }^{21}$ Objectives and Principles of Securities Regulation // Официальный сайт ИОСКО: <http://www.iosco.org/library/pubdocs/pdf/ IOSCOPD154.pdf $>$. органов надзора по имплементации принципов на уровне отдельных государств.

Третий сегмент - рынок страхования - регулируется Международной ассоциацией страховых надзоров (далее-ИАИС) $)^{22}$, учрежденной в 1994 году по законодательству Швейцарии в Базеле. В ассоциацию входят представители органов надзора государств из более 140 стран. Задачей ассоциации, является, среди прочего, разработка принципов, стандартов и руководств по надзору за рынками страхования ${ }^{23}$. Помимо органов страхового надзора в ассоциации присутствуют около 130 наблюдателей, представляющих различные международные организации, профессиональные ассоциации и страховые организации. Статус наблюдателя в ИАИС имеет Всероссийская ассоциация страховщиков.

К одним из основных документов, разработанных в рамках ИАИС, относятся одобренные в 2003 году «Основополагающие принципы и методология страхования» ${ }^{24}$. Данный документ, адресованный органам страхового надзора государств-членов ИАИС, представляет собой свод принципов, касающихся условий эффективного страхового надзора, системы надзора, поднадзорных организаций (главным образом, страховщиков), текущего надзора, пруденциальных требований, вопросов защиты прав потребителей, а также борьбы с отмыванием денег. На органы страхового надзора - членов ИАИС возложена обязанность по имплементации данных принципов в национальное законодательство. К примеру, «Основополагающие принципы и методология страхования» содержат Принцип 8, устанавливающий правила перехода контроля в страховых организациях. Поясняется, в частности, что страховщик не должен в одностороннем порядке изменять условия договора страхования в случае реорганизации страховой организации, а также в случае передачи другому страховщику части обязательств по страховому полису.

Представляет интерес документ под названием «Принципы проведения страхования», разрабо-

\footnotetext{
${ }^{22}$ Перевод Федеральной службы страхового надзора Российской Федерации.

${ }^{23}$ Art. 2 (2) (a) of the International Association of Insurance Supervisors (IAIS) Вy-Laws // Официальный сайт ИАИС: <http:// www.iaisweb.org/By-laws-45>.

${ }^{24}$ Insurance core principles and methodology, 2003 // Официальный сайт ИАИС: <http://www.iaisweb.org/Translations-JapaneseKorean-Portuguese-Russian-Spanish-443>.
} 
танный ИАИС в 1999 году. Так, к примеру, данные принципы содержат такие общие для гражданского законодательства правила, как добросовестность, запрет злоупотребления правом (Принцип 1), запрет конфликта интересов (Принцип 6). Как указано в данных Принципах, они «формируют основу для конкретных стандартов поведения на рынке», которые могут «иметь государственную поддержку, либо надзор за ними и правоприменение могут осуществляться профессиональными ассоциациями» в зависимости от того, «какое решение примет отдельная юрисдикция $\rangle^{25}$.

В настоящее время в рамках ИАИС разрабатывается «Общий свод правил надзора за страховыми группами, задействованными в международных операциях» (далее - ОСП) ${ }^{26}$. Работа над данным документом началась в 2010 году, а окончательный вариант для утверждения ИАИС планируется представить в 2018 году. ОСП призван унифицировать надзор за страховыми группами, задействованными в международных операция ${ }^{27}$. Такие группы будут определяться по двум критериям: международная активность и размер. Международная активность означает, во-первых, что страховые премии должны быть получены не менее чем из трех юрисдикций и, во-вторых, процент количества премий, полученных за пределами государства домицилия, должен быть не менее $10 \%$ от общего количества премий, полученных страховой группой. Второй критерий - размер страховой группы - означает, что общая сумма активов такой группы, рассчитываемая как средний показатель за предшествующие три года, должна быть не менее чем 50 млрд. долларов США, а количество полученных премий должно быть не менее 10 млрд. долларов США. Предполагается, что под вышеуказанные критерии и, следовательно, под пристальный надзор попадут не менее 50 существующих страховых групп.

Органы, указанные выше, способствуют развитию международного права и гармонизации наци-

\footnotetext{
${ }^{25}$ Principles for conduct of insurance business, 1999 // Официальный сайт ИАИС: <http://www.iaisweb.org/Translations-JapaneseKorean-Portuguese-Russian-Spanish-443>.

${ }^{26}$ IAIS Common Framework for the Supervision of Internationally Active Insurance Groups // Официальный сайт ИАИС: <http:// www.iaisweb.org/Common-Framework--765>

${ }^{27}$ IAIS Common Framework for the Supervision of Internationally Active Insurance Groups // Официальный сайт ИАИС: <http:// www.iaisweb.org/Common-Framework--765>
}

онального права, регулирующего международный финансовый рынок в целом, в том числе требования к участникам рынка и надзорным органам, заключаемым сделкам. Более того, вырабатываемые таким образом нормы оказывают существенное влияние не только на национальное законодательство, но на практику его применения, и на договорную практику, существующую на рынке.

\section{Место международного частного права в регулировании международного финансового рынка}

Для регулирования имущественных отношений на международных финансовых рынках большую значимость имеют нормы международного частного права и национального права. Отечественными авторами признается, что «валютные отношения между частными лицами, связанные с иностранным правопорядком (в том числе оборот ценных бумаг), сфера действия международного частного права» ${ }^{28}$. Нормы, регулирующие данные отношения, можно найти в международно-правовых актах и нормах национального законодательства.

Следует признать, что международные договоры регулируют не все, а лишь отдельные аспекты международных финансовых отношений. К таким договорам следует отнести Женевские вексельные и чековые конвенции 1930 года, Нью-Йоркскую конвенцию ООН о международных переводных и международных простых векселях 1988 года, Оттавскую конвенцию УНИДРУА о международном факторинге 1988 года, Типовой закон ЮНСИТРАЛ о международных кредитовых переводах 1992 года.

\section{Гаагская и Женевская конвенции}

Значительный вклад в область правового регулирования, касающегося международного финансового рынка ценных бумаг, внесли Гаагская конвенция о праве, применимом к определенным правам в отношении ценных бумаг, находящихся у посредника, 2006 года (далее - Гаагская конвенция) и Женевская конвенция УНИДРУА о материально-правовом регулировании ценных бумаг, находящихся у посредника, 2009 года (далее - Женевская конвенция).

\footnotetext{
${ }^{28}$ Гетьман-Павлова И.В. Коллизионное регулирование оборота ценных бумаг // Банковское право. 2007. № 5.
} 
Как видно из названия указанных документов, Гаагская конвенция содержит коллизионные нормы, а Женевская - материально-правовые.

Работа над Гаагской конвенцией началась в 2000 году под эгидой Гаагской конференцией по международному частному праву вслед за совместным предложением Австралии, Великобритании и США. Предлагалось создать в ускоренном режиме конвенцию, которая бы установила коллизионные нормы, распространяющиеся на отношения из ценных бумаг, удерживаемых через посредников, а также на отношения, связанные с передачей таких бумаг ${ }^{29}$. Гаагская конвенция устанавливает коллизионные правила, касающиеся правоотношений, которые возникают из сделок с ценными бумагами, находящимися у посредника. Структура Конвенции выглядит следующим образом: первая глава посвящена вопросам определений и сферы применения, вторая - применимому праву, третья касается общих положений, четвертая и пятая содержат переходные и окончательные положения.

Заслуживает внимания определение ценной бумаги, содержащееся в Гаагской конвенции: под ценной бумагой понимаются «любые акции, облигации или другие финансовые инструменты или финансовые активы (за исключением наличных денег), а также любое возникающее из них право». В пояснительном отчете к Гаагской конвенции указывается, что под финансовыми инструментами (активами) подразумевается любое денежное право требования, которое может выступать предметом имущественного оборота ${ }^{30}$. Разработчики конвенции намеренно

\footnotetext{
${ }^{29}$ Гаагская конвенция была подписана США, Швейцарией и Маврикием, а ратифицирована только Швейцарией и Маврикием. Гаагская конвенция еще не вступила в силу, поскольку для этого необходима ратификация, по крайней мере, трех стран. ЕС не ратифицировал Гаагскую конвенцию, несмотря на рекомендации, поскольку этот вопрос уже был решен на уровне законодательства ЕС: права, возникающие из ценных бумаг, находящихся у посредника, регулируются правом, где располагается счет, на котором учитываются эти бумаги. См.: Art. 9 (2) of the Settlement Finality Directive 98/26/EC; Art. 9 (1) of the Financial Collateral Arrangements Directive 2002/47/EC. B литературе данный принцип получил наименование PRIMA. См.: Ерпылева Н.Ю., Клевченкова М.Н. Коллизионное регулирование обращения ценных бумаг: частноправовые аспекты // Законодательство и экономика. 2009. № 6.

${ }^{30}$ Explanatory Report on the 2006 Hague Securities Convention, Brill Academic Publishers, 2005 // Официальный сайт Гаагской конференции по международному частному праву: <http:/www. hcch.net/index_en.php?act=publications.details\&pid=2955\&dtid=3>.
}

выработали как можно более широкое определение ценных бумаг, для того чтобы учесть изменения в рыночной практике. Единственный квалифицирующий признак ценных бумаг по смыслу конвенции - это факт того, что такая ценная бумага находится у посредника. К вопросам, урегулированным Гаагской конвенцией, разработчики отнесли следующие ${ }^{31}$ :

- правовая природа и правовые последствия прав, возникших в связи с внесением ценных бумаг на счет ценных бумаг в отношении посредника и третьих лиц;

- $\quad$ правовая природа и правовые последствия распоряжения ценными бумагами, находящимися у посредника;

- условия (при наличии таковых), выполнение которых делает распоряжение ценными бумагами, находящимися у посредника, действительным в отношении третьих лиц;

- существование приоритета или погашение права другого лица наличием права лица на ценные бумаги, находящиеся у посредника;

- обязанности посредника (при наличии таковых) в отношении какого-либо иного, кроме владельца счета, лица, заявляющего в отношении владельца счета или иного лица о своих конкурирующих правах на ценные бумаги, находящиеся у посредника;

- условия (при наличии таковых) осуществления права на ценные бумаги, находящиеся у посредника;

- возникновение путем распоряжения ценными бумагами, находящимися у посредника права на получение дивидендов, доходов или иных распределяемых выплат либо права на компенсации или иные поступления, связанные с передачей прав на ценные бумаги.

Гаагская конвенция не определяет право, применимое к 1) правам и обязанностям, возникающим из внесения ценных бумаг на счет ценных бумаг в той степени, в которой такие права и обязанности основаны исключительно на договоре или носят фидуциарный характер; 2) к договорным или иным личным правам и обязанностям сторон, связанным с распоряжением ценными бумагами, находящимися у посредника; 3) к правам и обязанностям эмитента ценных бумаг, или держателя реестра, или агента, независимо от того, относятся ли они к держателю

\footnotetext{
${ }^{31}$ Статья 2.1 Гаагской конвенции.
} 
ценных бумаг или любому другому лицу ${ }^{32}$. Иными словами, Гаагская конвенция не ограничивает автономию воли сторон, не содержит коллизионных норм, относящихся к порядку распоряжения ценными бумагами, и не касается правового положения эмитента или держателя реестра.

В отличие от принципа, закрепленного в праве $\mathrm{EC}$, Гаагская конвенция устанавливает правило, согласно которому правом, применимым к указанным выше вопросам будет право того государства, которое прямо указанно в соглашении о счете как право, регулирующее данное соглашение. Это, вероятно, объясняет, почему ЕС до сих пор не ратифицировал Гаагскую конвенцию (в праве ЕС закреплен иной принцип).

Таким образом, нормы, содержащиеся в конвенции, носят диспозитивный характер и применяются, если соглашением сторон не предусмотрено иное. Некоторые авторы указывают на неэффективность и «излишнюю сложность» Гаагской конвенции ${ }^{33}$, а также на тот факт, что она представляет собой «классический пример отказа от адаптации традиционных коллизионных принципов к новым явлениям в международной среде ${ }^{34}$. Тем не менее, в 2006 году Группа тридцати выразила рекомендацию ратифицировать Гаагскую конвенцию «как можно большим количеством государств» и «как можно скорее» ${ }^{35}$.

Женевская конвенция разрабатывалась под эгидой УНИДРУА. Следует отметить, что с 2001 года в рамках УНИДРУА ведется проект «Сделки на транснациональных и связанных рынках капитала». В рамках этого проекта в 2005 году институтом было принято решение изучить принципы и правила, способствующие торговле ценными бумагами на развивающихся рынках ${ }^{36}$.

\footnotetext{
${ }^{32}$ Статья 2 (3) Гаагской конвенции.

${ }^{33}$ Канашевский В.А. Коллизионное регулирование ценных бумаг: состояние и перспективы // Журнал российского права. 2011. № 9.

${ }^{34}$ Выговский А. И. Бездокументарные ценные бумаги как объекты коллизионно-правового регулирования // Налоги. 2012. № 15 .

${ }^{35}$ Global Clearing and Settlement. Final Monitoring Report. Group of Thirty. Washington, 2006. P. 36 // Официальный сайт группы 30: <http://www.group30.org/images/PDF/Global\%20 Clearing\%20and\%20Settlement $\% 20$ Final\%20Monitoring $\% 20$ Report\%202006.pdf>.

${ }^{36}$ Study LXXVIII B of Institute for the Unification of Private Law: Principles and rules capable of enhancing trading in securities emerging markets // Официальный сайт УНИДРУА: <http://www. unidroit.org/English/studies/study78b/main.htm>.
}

Результатом стала разработка Женевской конвенции. Ее целью является «усовершенствование правового режима владения, передачи, передачи в качестве обеспечения ценных бумаг при помощи посредников или ценных бумаг, находящихся у посредника, для того, чтобы улучшить внутреннюю устойчивость национальных финансовых рынков и их трансграничную совместимость и, как следствие, способствовать приращению капитала» ${ }^{37}$. Женевская конвенция состоит из шести глав: первая глава посвящена определениям, сфере применения и толкованию; вторая глава содержит вопросы, относящиеся к правам держателя счета ценных бумаг, находящихся у посредника; третья глава касается порядка передачи ценных бумаг, находящихся у посредника; четвертая регулирует вопросы единства посреднических систем учета; пятая касается обеспечительных сделок; пятая и шестая включают переходные и окончательные положения.

Женевская конвенция содержит определение ценных бумаг, по существу аналогичное Гаагской конвенции. Как и Гаагская конвенция, Женевская конвенция распространяется на ценные бумаги, а также права, возникающие из таких ценных бумаг. Однако в отличие от Гаагской конвенции, которая содержит один квалифицирующий признак (факт учета ценных бумаг через посредника), Женевская конвенция содержит два критерия. Во-первых, чтобы подпадать под действие конвенции, ценная бумага должна иметь свойство быть способной учитываться на счете ценных бумаг у посредника ${ }^{38}$. Во-вторых, порядок приобретения и распоряжения такой ценной бумагой должен соответствовать положениям Конвенции ${ }^{39}$.

\section{Принципы УНИДРУА о ликвидационном неттинге}

В мае 2013 года в рамках УНИДРУА был принят свод Принципов, касающихся условий о ликвидационном неттинге (далее - Принципы неттинга). Поскольку данный документ является относительно новым и пока еще не был должным образом исследован в отечественной юридической литературе, остановимся более подробно на его значении и содержании.

\footnotetext{
37 Official Commentary on the UNIDROIT Convention on Substantive Rules for Intemediated Securitites. Oxford University Press, 2012. P. 1.

${ }^{38}$ Статьи 1(c) и 1 (d) Женевской конвенции.

${ }^{39}$ Статьи 11 и 12 Женевской конвенции.
} 
Вопрос о юридической силе Принципов неттинга остается открытым. Данные Принципы, адресованные государствам, отражают формирующееся мировое правосознание в сфере обязательств, возникающих из клиринга, взаимозачета и неттинга, и не исключено, что они в определенной степени окажут влияние на национальные правовые режимы ${ }^{40}$. Принципы неттинга используют термин «Имплементирующее государство», адресуя тем самым содержащиеся в них правила соответствующим государствам с тем, чтобы последние отразили дух данных принципов в национальном законодательстве и таким образом сближали правовые режимы.

Принципы неттинга содержат 8 Принципов, касающихся сферы применения, понятия ликвидационного неттинга, определения сторон условий о ликвидационном неттинге, предмета таких условий, формальных требований национального законодательства к таким условиям, действительности таких условий, в том числе в процедурах несостоятельности финансовых институтов. Принципы касаются условий о ликвидационном неттинге. Согласно Принципу 2 Условие о ликвидационном неттинге означает «договорное условие, на основании которого при наступлении заранее определенного события в отношении стороны по договору обязательства каждой из сторон, покрываемые таким условием, независимо от того, наступил ли срок по таким обязательствам, и подлежат ли они исполнению или нет, автоматически или по выбору одной из сторон таких обязательств уменьшаются в размере или такие обязательства заменяются единым обязательством путем новации, прекращения или каким-либо другим способом, представляя совокупную сумму общих обязательств, которая в такой момент подлежит оплате одной стороной в пользу другой стороны» ${ }^{41}$

Данное определение достаточно громоздко, но по замыслу разработчиков Принципов неттинга

\footnotetext{
${ }^{40}$ Разработчики отражают связь данных принципов с другими документами, принятыми в сфере международных финансовых отношений, ссылаясь на «Основные признаки специальных правовых режимов, вводимых государствами в случае финансовых кризисов», разработанные Форумом финансовой стабильности, о которых было упомянуто выше.

${ }^{41}$ Annex to the Report on the completion of the intergovernmental negotiations on the Draft Principles, and request for their adoption by the Governing Council, as approved by the UNIDROIT Committee of governmental experts in March 2013. UNIDROIT, 2013. C.D. (92) 6 (a).
}

оно было сформулировано для того, чтобы покрыть как можно большее количество соответствующих договорных условий. Заслуживает внимания подход, избранный разработчиками Принципов неттинга в отношении сферы их применения. Как видно, ликвидационный неттинг - это сделка, которая может быть заключена либо под отлагательным условием (наступление определенного события), результатом которого становится новация или прекращение обязательств, либо которая при определенном событии дает право одной из сторон требовать новации, прекращения обязательств. Следует отметить, что по смыслу российского права следует говорить именно о новации, поскольку результатом является новое обязательство, предусматривающее иной способ исполнения. В результате такой новации ряд существующих между сторонами обязательств прекращается и остается одно обязательство, в соответствии с которым одна из сторон остается обязанной уплатить определяемую в результате такого неттинга сумму.

Природа ликвидационного неттинга становится более ясной на примере рыночной практики. На национальных финансовых рынках, так же как и на международном, инвесторы ежедневно заключают множество различных сделок с ценными бумагами (купля-продажа, залог и другие), деривативами (опционные, форвардные, фьючерсные контракты), валютой, драгоценными металлами (купля-продажа золота, серебра, платины и других) и другими активами. Исполнение по таким сделкам обычно происходит не сразу, а по истечении определенного периода времени. В нормальных рыночных условиях по большинству сделок реального исполнения не происходит, а стороны заранее либо впоследствии договариваются произвести взаимозачет, в результате которого только одной из сторон производится исполнение - той, у которой оказалось больше долгов.

Однако во времена экономических кризисов клиринговый механизм может не сработать: многие предприятия оказываются неплатежеспособными и попадают под процедуры несостоятельности, и в таких случаях применяется условие о ликвидационном неттинге - поэтому он и называется ликвидационным. Все обязательства, существующие между сторонами, суммируются, и высчитывается разница, которую составляют взаимные обязательства, в результате - одна из сторон становится должником, а другая кредитором. Ссылка в Принципах неттинга на «договорное условие» по замыслу разработчиков 
касается практики, когда условие о ликвидационном неттинге включается в стандартную документацию, служит предметом рамочного или самостоятельного соглашения между сторонами. В этих целях Принципы неттинга оперируют понятием «условие» о ликвидационном неттигне, чтобы охватить как можно больший перечень договоров и соглашений ${ }^{42}$.

Принципы распространяются на условия о ликвидационном неттинге, заключаемые между «отвечающими требованиям Принципов сторонами» в отношении «отвечающих требованиям Принципов обязательств» ${ }^{43}$. Таким образом, Принципы неттинга устанавливают два основных критерия: по субъектному составу и по предмету соглашения.

Принцип 3 дает определение «отвечающим требованиям Принципов неттинга сторон», понимая «любое физическое или юридическое лицо, за исключением физического лица, действующего, главным образом, для личных, семейных или домашних целей, включая товарищество, фактически действующую ассоциацию или какой-либо другой орган или лицо» ${ }^{44}$. К таким лицам, по смыслу Принципов неттинга, относятся квалифицированные участники финансового рынка и публичные лица. Под квалифицированными участниками финансового рынка понимаются:

- банки, инвестиционные фирмы, профессиональные брокеры, которые подлежат регулированию или пруденциальному надзору;

- страховщики и перестраховщики;

- $\quad$ предприятия коллективного инвестирования или инвестиционные фонды;

42 По смыслу российского законодательства речь будет всегда идти о сделке.

${ }^{43}$ В оригинале Принцип 1(1) выглядит так: «These Principles deal with the operation of close-out netting provisions that are entered into by eligible parties in respect of eligible obligations». Английский термин «eligible» имеет два основных значения: «имеющий право» (в силу удовлетворения соответствующим установленным требованиям) и «отвечающий требованиям». Исходя из общего содержания Принципов неттинга, данный термин употреблен во втором значении.

${ }^{44}$ Как видно, определение круга лиц, на которых распространяются Принципы неттинга, достаточно широко и позволяет включить максимальное число участников финансового рынка. Исключение было сделано лишь для физических лиц, действующих, главным образом, для личных, семейных или домашних целей - аналогичный подход был использован в Венской конвенции о договорах международной купли-продажи товаров 1980 года. Такое исключение было сделано для того, чтобы исключить применения норм о защите прав потребителей.
- центральные контрагенты или платежные, клиринговые системы, системы взаимозачета или операторы таких систем, которые (в любом случае) подлежат регулированию или пруденциальному надзору;

- $\quad$ корпорации или другие лица, которые в соответствии с критериями Имплементирующего государства уполномочены или находятся под надзоров в качестве важных участников рынков такого Имплементирующего государства, давая основания для отвечающих требованиям Принципов обязательств.

Ко второй группе лиц Принципы неттинга относят «публичные органы», среди которых выделяют:

- правительственные или любые другие публичные лица;

- центральные банки;

- Банк для международных расчетов, многосторонние банки развития, МВФ или любые другие подобные лица.

Определение «отвечающих требованиям Принципов обязательств», содержащееся в Принципе 4, отражает основную суть Принципов: в нем перечисляются те сделки, которые могут служить предметом условий о ликвидационном неттинге. Под «отвечающим требованиям Принципов обязательством» понимается:

(a) «обязательство, возникающее по любому из следующих договоров между отвечающими требованиям Принципов сторонами, по крайней мере одна из которых является публичным лицом или квалифицированным участником финансового рынка:

i. деривативные инструменты, то есть опционы, форварды, фьючерсы, свопы, контракты на разницу и любые другие сделки в отношении соответствующей отсылки или базового актива, которые являются или в будущем будут являться предметом возвратных контрактов на рынках деривативов;

ii. сделки РЕПО, соглашения о займе ценных бумаг и любые другие сделки финансирования ценными бумагами, совершаемые в любом случае в отношении ценных бумаг, инструментов денежного рынка или активов в предприятиях коллективного инвестирования или инвестиционных фондах;

iii. обеспечительные соглашения по передаче прав, относящиеся к отвечающим требованиям Принципов обязательствам; 
iv. онтракты на продажу, покупку или поставку

а. ценных бумаг;

б. инструментов денежного рынка;

в. активов в предприятиях коллективного инвестирования или инвестиционных фондах;

г. валюты любой страны, территории или валютного союза; золота, серебра, платины, палладиума или другого драгоценного металла

(b) обязательство отвечающей требованиям Принципов стороны (независимо от того, выступает ли такая сторона лицом, предоставляющим обеспечение, либо основным должником) исполнить обязательство третьего лица, которое является отвечающим требованиям Принципов обязательством в соответствии с пунктом (а) выше;

(c) единое «чистое» обязательство, определяемое в соответствии с условием о ликвидационном неттинге, заключенным между теми же сторонами в отношении обязательств, перечисленных в пунктах (a) или (b) выше.

Принцип 4 устанавливает, что Имплементирующее государство может расширить сферу применения вышеуказанного пункта 1 следующими способами: во-первых, предусматривая, что к данным обязательствам относятся также те, которые возникают между сторонами, ни одна из которых не является публичным лицом или квалифицированным участником финансового рынка; во-вторых, расширив список обязательств, перечисленных выше.

Принципы 5-8 содержат правила, непосредственно относящиеся к условиям о ликвидационном неттинге. Принцип 5 устанавливает, что действие условий о ликвидационном неттинге не должны находиться в зависимости от 1) каких-либо формальных предписаний, кроме того, что условие о ликвидационном неттинге должно быть совершено в письменной или любой другой эквивалентной форме; 2) использования стандартных терминов специальной торговой ассоциации ${ }^{45}$. Тем не менее, предусматривается право Имплементирующего

\footnotetext{
${ }^{45}$ Под термином «действие» в принципах понимается «возникновение, действительность, правовая защита, исполнимость в отношении третьих лиц и допустимость в качестве доказательства условия о ликвидационном неттинге» (Принцип 1(2)).
}

государства устанавливать требования отчетности в отношении условий о ликвидационном неттинге для целей регулирования.

Принцип 6 содержит правила, касающиеся действия условий о ликвидационном неттинге в общем, а Принцип 7 устанавливает правила, касающиеся действия условий о ликвидационном неттинге, применяемые в процедурах несостоятельности и специальных режимах, в то время как Принцип 8 устанавливает, что действие Принципов не распространяется на действия Имплементирующего государства, принимаемые в отношении финансовых институтов. Принцип 6 по существу предписывает Имплементирующим государствам не устанавливать императивные правила в отношении условий о ликвидационном неттинге, кроме общих принципов действительности сделок. Принцип 7 возлагает на Имплементирующее государство обязанность на законодательном уровне закрепить особые правила в отношении условий о ликвидационном неттинге в процедурах несостоятельности. Данный принцип предусматривает следующие правила, касающиеся действительности условий о ликвидационном неттинге в процедурах о несостоятельности:

- условия о ликвидационном неттинге не должны признаваться недействительными (приостанавливаться);

- $\quad$ государственные органы не должны иметь полномочий отказывать в судебной защите лишь некоторых обязательств, покрываемых условием о ликвидационном неттинге, одновременно отказывая в судебной защите других покрываемых таким условием обязательств;

- одно лишь заключение условий о ликвидационном неттинге не должно рассматриваться в качестве нарушения правила равенства кредиторов;

- условия о ликвидационном неттинге не должны признаваться недействительными на том основании, что они заключаются или исполнение по ним производится непосредственно до начала процедуры несостоятельности.

Тем не менее, Принцип 6 касается таких фундаментальных положений законодательства, как недобросовестность: к примеру, условия о ликвидационном неттинге могут быть признаны недействительными, если одна из сторон по сделке знала о возможной процедуре несостоятельности. 


\section{Европейские конвенции о валютных обязательствах}

Все перечисленные документы тем или иным образом затрагивают отношения, возникающие на международном финансовом рынке: вексельные отношения, исполнение уступка прав по международным кредитным договорам, отношения, связанные с трансграничным выпуском ценных бумаг и торговлей ими. Однако существует две европейские конвенции, посвященные валютным обязательствам в целом, которые не нашли поддержки и должного внимания ни среди государств, ни среди отечественных ученых. Первая из них - Европейская конвенция о денежных обязательствах, выраженных в иностранной валюте, разработанная Советом Европы в 1967 году (далее - Конвенция 1967 года) ${ }^{46}$. Вторая - Европейская конвенция о месте выплат по денежным обязательствам, разработанная Советом Европы в 1972 году (далее - Конвенция 1972 года) ${ }^{47}$. Обе конвенции содержат материально-правовые нормы, затрагивающие валютные обязательства, исполнение по ним, а также их судебную защиту.

Конвенция 1967 года была подписана Австрией, Францией, Германией и Люксембургом, а ратифицирована только Люксембургом. Конвенция была разработана соответствующим комитетом экспертов, созданным в 1965 году в рамках Совета Европы. В задачи комитета входил анализ проекта конвенции, который был предложен другой международной организацией - Ассоциацией международного права. Конвенция преследовала три основных цели ${ }^{48}$. Во-первых, она устанавливала право должника осуществить платеж по обязательству в национальной валюте, несмотря на то, что обязательство могло быть выражено в валюте, отличной от валюты места исполнения. Во-вторых, она закрепляла право креди-

\footnotetext{
${ }^{46}$ Конвенция не вступила в силу. Конвенция ратифицирована Люксембургом, подписана Австрией, Германией и Францией // Официальный сайт Совета Европы: <http://conventions. coe.int/treaty/Commun/ChercheSig.asp?NT $=060 \& \mathrm{CM}=8 \& \mathrm{D}$ $\mathrm{F}=21 / 03 / 2013 \& \mathrm{CL}=\mathrm{RUS}>$.

47 Конвенция не вступила в силу. Подписана Австрией, Германией и Нидерландами // Официальный сайт Совета Европы: $<$ http://conventions.coe.int/treaty/Commun/ChercheSig. asp? $\mathrm{NT}=075 \& \mathrm{CM}=8 \& \mathrm{DF}=21 / 03 / 2013 \& \mathrm{CL}=\mathrm{RUS}>$.

${ }^{48}$ Explanatory Report to European Convention on Foreign Money Liabilities (ETS No. 60) // Официальный сайт Совета Европы: $<$ http://conventions.coe.int/Treaty/en/Reports/Html/060.htm>.
}

тора требовать возмещения убытков, причиненных в результате просрочки платежа, если в течение периода такой просрочки курс валюты обязательства, подлежащего исполнению, снижается по отношению к валюте места платежа. В-третьих, она предусматривала право кредитора в случае судебного разбирательства требовать вынесения решения в валюте обязательства, а не только в валюте форума ${ }^{49}$.

Из текста Конвенции 1967 года становится ясным, почему она не пользуется популярностью среди государств-членов Совета Европы: предусматривая право должника произвести исполнение в местной валюте, Конвенция тем самым нивелирует выгоду, которую получают кредиторы от валютных сделок. Во-первых, сделки, содержащие обязательство должника, выраженное в определенной валюте и подлежащее исполнению в определенный срок, заключаются с тем, чтобы, несмотря на изменившийся валютный курс, закрепить право кредитора требовать обратно ту же сумму в той же валюте. Подобные сделки выступают определенной «страховкой» от валютных рисков; они могут выступать в качестве валютных оговорок в различных внешнеторговых контрактах. Во-вторых, применение Конвенции 1967 года исключило бы участие в коммерческом обороте сторон из развивающихся государств или государств, чья валюта не пользуется спросом на рынке, поскольку маловероятно, что кредиторы согласились бы предоставить таким должникам средства в валюте, одновременно принимая на себя риск получить обратно другую, невостребованную на рынке валюту, валюту нестабильной страны. Тем не менее, несмотря на очевидные недостатки Конвенции 1967 года, некоторые юристы призывают вновь к выработке единой конвенции ${ }^{50}$.

Конвенция 1972 года посвящена определению места платежа по валютным обязательствам и содержит всего пять статей. Основной принцип, закрепленный в Конвенции 1967 года, содержится в пункте 1 Статьи 2: «платеж должен быть произведен по месту обычного нахождения кредитора в момент платежа $\iota^{51}$. Однако в пункте 2 этой же статьи предус-

\footnotetext{
${ }^{49}$ European Convention on Foreign Money Liabilities, Paris 11 December 1967 // Официальный сайт Совета Европы: <http:// conventions.coe.int/Treaty/EN/Treaties/Html/060.htm>.

${ }^{50}$ Black $V$. Foreign Currency Obligations in Private International Law. Hague Academy of International Law, 2004. P. 165-190.

${ }^{51}$ European Convention on the Place of Payment of Money Liabilities,
} 
матривается право кредитора требовать исполнения в любом другом месте, при этом такое право возникает в момент неисполнения обязательства должником. Расходы, связанные с изменением места оплаты, в соответствии со статьей 4 , несет кредитор. Тем не менее, статьей 3 предусматривается право должника отказаться от исполнения в другом месте, если последствия такого исполнения будут значительным образом обременительны для должника.

\section{Саморегулирование на международном финансовом рынке}

В регулировании отношений на международном финансовом рынке большую роль играет разработка стандартной документации самими участниками рынка. Создаваемые в рамках такой документации правила формируют так называемые «частные правовые режимы ${ }^{52}$, которые в будущем могут играть значительную роль в системе регулирования международных частных отношений.

Стандартные документы можно рассматривать как специфическую форму правового обычая. Как отмечал Е.Н. Трубецкой, «обычай наряду с прецедентом и после него, есть, несомненно, древнейшая форма позитивного права, которая предшествовала закону, существовала раньше образования государства; и, тем не менее, до начала XIX столетия никому из ученых не приходило в голову признавать юридический обычай за самостоятельную форму права $<. .>$ не только у дикарей, но и у народов, стоящих на высокой ступени развития, где правовые отношения определяются не одним законом, но и рядом норм, сложившихся путем обычая» ${ }^{53}$.

Basle 16 Мау 1972 // Официальный сайт Совета Европы: <http:// conventions.coe.int/Treaty/EN/Treaties/Html/075.htm>

${ }^{52}$ Welsch D. Global Law's Toolbox: Private Regulation by Standards. The American Journal of Comparative Law. Vol. 60. P. 1110.

${ }^{53}$ Трубецкой Е.Н. Энциклопедия права. М.: Юиридический институт (Санкт-Петербург), 1998. С. 82. Следует заметить, что в настоящее время стандартные документы определенным образом являются производными от норм национального права. По справедливому замечанию Боджиано в международном частном праве стандартные условия и статьи договоров состоят из материальных правил, инкорпорированных сторонами в договор. См.: Boggiano A. International Standard Contracts // Collected courses of the Hague Academy of International Law. 1981. Vol. 1. Р. 20. Стандартные документы создаются с учетом того, чтобы впоследствии исключить недействительность за-
Г.В. Петрова понимает под «типовым международным финансовым контрактом» «типовые (общие) условия заключения, гарантии исполнения и прекращения кредитных, расчетных, клиринговых, депозитарных, доверительных по ценным бумагам, инвестиционных, налоговых, страховых договорных отношений с иностранным элементом» ${ }^{54}$. Вопрос того, можно ли урегулировать «налоговые отношения с иностранным элементом» в типовом финансовом контракте, является спорным. По всей видимости, Г.В. Петрова имеет в виду широко используемое в международной договорной практике стандартное условие о том, что все платежи в пользу кредитора должны производиться с вычетом применимых налоговых платежей, при этом связанные с такой выплатой издержки возлагаются на должника (оговорка «tax gross up»). Далее Г.В. Петрова отмечает, что «типовые финансовые контракты выступают орудием внедрения в международно-правовую финансовую сферу существующих обычаев банковской, инвестиционной, страховой, валютной и иной финансовой деятельности» ${ }^{55}$.

На международном финансовом рынке разработка стандартных документов адресована различным секторам рынка. Так, для рынка международных синдицированных займов большое значение играют правила, разрабатываемые Лондонской кредитной ассоциацией (далее - ЛМА). В настоящее время в рамках Ассоциации региональных банков «Россия» с привлечением международных юридических консультантов и с поддержкой ЕБРР разрабатываются типовые договоры синдицированного кредита и кредита для малого и среднего бизнеса на основе стандартной документации ЛМА, а также типовые формы обеспечительных договоров ${ }^{56}$.

ключаемых на основе таких условий сделок, в том числе на том основании, что они не соответствуют национальному праву. Так, стандартная документация ЛМАС разрабатывается с учетом английского права. Изучение стандартной документации представляет определенную сложность, а английский юрист Йетс указывает, что стандартные договоры похожи на слонов: «мы можем определить их, когда их увидим, но их чертовски сложно описать». См.: Yates D. Standard business contracts: exclusions and related devices. London: Sweet \& Maxwell, 1986. P. V.

${ }^{54}$ Петрова Г.В. Международное финансовое право: Учебник. М.: Издательство Юрайт, 2011. С. 71.

55 Там же. С. 74.

56 Официальный сайт Ассоциации региональных банков «Россия»: $<$ http://www.asros.ru/ru/>. 
Разработкой правил в другом сегменте - рынке капиталов - занимается Международная ассоциация рынков капитала (далее - МАРК). МАРК была создана в 1969 году с головным офисом в Швейцарии с первоначальным фокусом на рынках капитала ${ }^{57}$. В 1969 году в ответ на кризис на еврорынке была образована «Ассоциация облигационных дилеров», которая впоследствии была переименована в «Международную ассоциацию рынка ценных бумаг». В 1984 году создается «Международная ассоциация первичного рынка», целью которой было создание рекомендаций по практике эмиссии. В 2005 году эти две ассоциации объединились, чтобы образовать единую ассоциацию - «Международную ассоциацию рынков капитала». В отличие от ЛМА, которая представляет лондонские банки, то есть только кредиторов, МАРК представляет как кредиторов (эмитентов), так и должников. Участниками ассоциации являются дилеры и брокеры рынка ценных бумаг, региональные и коммерческие банки, частные банки, управленцы активами, инвестиционные банки и эмитенты.

Третьим сегментом - рынком производных финансовых инструментов - занимается Международная организация свопов и деривативов (далее - ИСДА). Данная организация была создана в 1985 году для того, чтобы «сделать внебиржевые рынки более эффективными $»^{58}$. ИСДА насчитывает более 800 членов из 60 стран, среди которых различные корпорации, в том числе энергетические компании, инвестиционные менеджеры, правительства и наднациональные организации, страховые организации, международные и региональные банки. Основной документ, разработанный ИСДА - это Генеральное соглашение ИСДА, на основе которого могут заключаться различные внебиржевые сделки. На российском рынке Генеральное соглашение ИСДА используется, как правило, дочерними банками иностранных кредитных организаций и фактически представляет собой русский перевод или перевод основанных на нем типовых соглашений материнских банков ${ }^{59}$.

\footnotetext{
${ }^{57}$ ICMA Overview brochure // Официальный сайт МАРК: <http:// www.icmagroup.org/assets/documents/Media/Brochures/2013a/ ICMA-overview-Feb-2013.pdf>.

${ }^{58}$ Официальный сайт ИСДА: $<$ http://www2.isda.org/about-isda/>.

${ }^{59}$ Селивановский А. Рамочные договоры о срочных сделках (деривативах) // Рынок ценных бумаг. 2008. № 7. С. 15-17.
}

Таким образом, правовое регулирование международных частных финансовых отношений - сложный комплексный процесс, в который вовлечены государства, международные правительственные неправительственные и организации, ассоциации участников международного финансового рынка. Регулирование осуществляется разными методами: методами международного права, международного частного права, национального права, а также так называемого «мягкого права» и методом lex mercatoria. Результатом деятельности регуляторов - как государств, так и участников рынка - являются две основных группы правил, устанавливающих (a) права и обязанности государств и государственных органов в отношении правового регулирования международного финансового рынка и надзора за участниками данных рынков, и (б) типовые условия сделок, заключаемых между участниками международных частных финансовых отношений.

\section{Международные сделки как основание возникновения частных правоотночений на международном финансовом рынке}

Как отмечалось А.П. Дудиным, «именно категория правоотношения $<\ldots>$ позволяет рассматривать право не только с точки зрения формы, как противополагаемые фактическим общественным отношениям юридические нормы (законы), то есть не как нечто только субъективное, идеальное, но и с точки зрения содержания, то есть одновременно с двух противоположных сторон: субъективной и объективной, формальной и содержательной, как единство идеального и материального, норм права и защищаемых ими интересов и потребностей, правового сознания и правового бытия, права как явления и права как сущности» ${ }^{60}$. Несмотря на то, что данный метод носит диалектический характер, он, позволяет наиболее полно описать складывающиеся на международном финансовом рынке правоотношения. По мнению Ю.И. Гревцова, «изучение только или главным образом норматива, т.е. действующей нормы законодательства, не в состоянии обеспечить реальную картину возникновения правовых общественных отношений, их роли в осуществлении правовых возможностей и юридических обязанностей

\footnotetext{
60 Дудин А.П. Диалектика правоотношения. Саратов: Издательство Саратовского университета, 1983. С. 3.
} 
субъектами права» ${ }^{61}$. Утверждение Ю.И. Гревцова как никогда справедливо применительно к сложным по своей структуре отношениям, возникающим на международных финансовых рынках, участниками которых являются лица различных государств и правовых традиций.

\section{Понятие международного финансового правоотночения}

Правоотношение - это урегулированное правом отношение одного лица к другим лицам ${ }^{62}$. Элементами всякого правоотношения являются правомочие, обязанность (иными словами, содержание правоотношения), субъект, обладающий правом, и объект права.

Вопрос о том, что же является объектом правоотношения - действия лица или само лицо - является спорным. Е.Н. Трубецкой утверждал, что «содержание права составляет не интерес, а свобода лица, и, соответственно этому, объектом права является все то, что может входить в сферу внешней свободы, что может сделаться предметом человеческого господства. Такими предметами, а, следовательно, и объектами права могут быть, во-первых, предметы вещественного мира - вещи; во-вторых, - действия лица и, наконец, в третьих, - само лицо» ${ }^{63}$.

Сомнительно, как в современных отношениях лицо может стать предметом человеческого господства, однако такой же позиции придерживался и С.А. Муромцев: «...права, принадлежащие к типу обязательств, или права личные, отличаются тем, что объектом правового отношения является в них не вещь, а лицо. Так, например, в праве по займу кредитору принадлежит возможность потребовать от должника уплаты занятых денег. Нарушение такого права может произойти только со стороны этого лица - объекта. Отсюда следует, что то же лицо (должник) является и объектом юридического отношения» ${ }^{64}$.

Напротив, иной позиции придерживался А.К. Стальгевич, который утверждал, что объектом

\footnotetext{
${ }^{61}$ Гревияов Ю.И. Правовые отношения и осуществление права. Ленинград: Издательство ЛГУ, 1987. С. 38.

${ }^{62}$ Трубеиякой Е.Н. Энциклопедия права. М.: Юридический институт (Санкт-Петербург), 1998. С. 123.

${ }_{63}^{6}$ Там же. С. 144.

${ }^{64}$ История русской правовой мысли. М.: Издательство Остожье, 1998. C. 181.
}

правоотношения (субъективных прав и обязанностей) являются: 1) фактическое общественное отношение и 2) вещи, действия, неимущественные интересы ${ }^{65}$. А.Б. Дудин под объектом правоотношения понимал предмет, на который направлена деятельность субъектов правоотношения, осуществляемая в процессе реализации ими своих юридических прав и обязанностей ${ }^{6}$. Не вдаваясь в дискуссии о том, является ли объектом правоотношения лицо, вещи, действия, имущественные интересы или что-либо еще, далее мы будем исходить из того, что объектом правоотношений на международных финансовых рынках являются, главным образом, вещи и действия лиц.

Международные финансовые правоотношения - это урегулированные правом общественные отношения, возникающие на международных финансовых рынках. Характеристика и основные особенности международных финансовых отношений, а также права, регулирующего данные отношения, были рассмотрены выше. Попробуем далее определить, какие именно отношения на международных финансовых рынках урегулированы правом или, иными словами, какие бывают правоотношения на международном финансовом рынке.

В отечественной доктрине сложилось неоднозначное и противоречивое мнение о том, что собой представляют международные финансовые правоотношения. По мнению Г.В. Петровой, отличительной особенностью данных отношений является то обстоятельство, что они выходят за рамки правовой системы одного государства; в них участниками являются физические и юридические лица, принадлежащие к разным государствам; они представляют собой «финансовые отношения лиц, вытекающие из международного финансового оборота, общения, международной жизни» ${ }^{67}$. Наиболее значимым выглядит признак, касающийся «международного финансового оборота», под которым автор подразумевает оборот международных финансовых инструментов. Далее Г.В. Петрова приводит следующие виды международных финансовых правоотношений ${ }^{68}$ :

\footnotetext{
${ }^{65}$ Стальгевич A. К. Некоторые вопросы теории социалистических отношения // Советское государство и право. 1957. № 2. C. 29-31.

${ }^{66}$ Дудин А.П. Указ. соч. С. 68.

${ }^{67}$ Петрова Г.В. Указ. соч. С. 46.

${ }^{68}$ Там же. С. 47-48.
} 
1. сложные международные финансовые правоотношения, возникающие в результате создания и деятельности авторитетных международных организаций в системе ООН (МВФ, ОЭСР, МБРР, МАГИ, ФАТФ и другие);

2. международные финансовые правоотношения на базе генеральных соглашений, требующих заключения конкретных договоров о реализации их принципов и задач (к таким, например, относятся договоры о финансовой помощи и гарантиях со стороны МВФ);

3. международные финансовые правоотношения, однородные по составу участвующих субъектов (например, транснациональные соглашения и операции кредитных организаций на финансовых рынках);

4. международные финансовые правоотношения на основе бессрочных и временных финансовых договоров, опосредующие длящиеся и одновременные правоотношения (например, международные соглашения о предотвращении двойного налогообложения заключаются на неопределенный срок, единовременными являются договоры о порядке выплат для погашения внешних долгов);

5. международные гарантийные финансовые правоотношения, направленные на обеспечения гарантий исполнения какого-либо другого финансового правоотношения;

6. международные финансовые правоотношения, вытекающие из «договоров-законов» и «договоров-сделок»; и те, и другие финансовые договоры являются источниками права, различие состоит в том, что договоры-сделки одновременно создают и норму права, и обязанности сторон (например, договор о расчетах аккредитивами, векселями, клиринговыми зачетами обязательств и др.), а договоры-законы рассчитаны на то, что будут регламентировать правоотношения, которые могут возникнуть в будущем;

7. международные финансовые правоотношения, возникающие на основе решений, рекомендаций и принципов международных организаций (например, Базельское соглашение о стандартах банковских активов и принципы организации банковского надзора).

Как видно, правоотношения, приводимые в пример Г.В. Петровой, в большей степени международные и публичные, хотя не исключаются и частно-правовые отношения.
Подобная позиция, при которой публичные и частные международные финансовые отношения рассматриваются в едином комплексе - отличительная характеристика отечественной доктрины. В частности, А.Б. Альтшулер выделял международное валютное право, куда включал «все юридические нормы, регулирующие международные валютные отношения, будь то международно-правовые, государственно- и административно-правовые, гражданско-правовые, регулирующие отношения с иностранным элементом» и обосновывал это тем, что «решающее значение имеет характер отношений, предмет регулирования, а не метод регулирования» ${ }^{69}$. В своих рассуждениях Г.В. Петрова придерживается аналогичной позиции: международное финансовое право - это «совокупность норм международной $и$ национальной ${ }^{70}$ принадлежности, регулирующих финансовые операции любого рода, при условии, что эти финансовые операции выходят за пределы правовой системы одного государства» ${ }^{71}$. Такой же точки зрения придерживается и А.Б. Беляев, утверждая, что основу международного финансового права составляет международное частное валютное право и международное (публичное) валютное право ${ }^{72}$. Аналогичной позиции придерживается и М.А. Шаповалов ${ }^{73}$.

В некоторой степени можно согласиться с позициями А.Б. Альтшулера и его последователей: действительно, особую роль в международных финансовых отношениях имеет характер этих отношений. Однако А.Б. Альтшулер исходил из иных экономических отношений, существовавших в начале их динамичного развития (70-80-х годах), с позиций социалистической правовой мысли. В настоящее время отношения на международном финансовом рынке, и это следует из рассуждений, приведенных в первом параграфе настоящей главы,

\footnotetext{
${ }^{69}$ См.: Альтшулер А.Б. Международное валютное право. М.: Международные отношения, 1984; Альтшулер А.Б. Правовые формы научно-технического и промышленного сотрудничества СССР с капиталистическими странами. М.: Издательство «Наука», 1980; Альтшулер А.Б. Международное валютное право. - М.: Международные отношения, 1984. С. 35-38.

${ }^{70}$ Курсив мой - прим. авт.

${ }^{71}$ Петрова Г.В. Указ. соч. С. 17.

${ }^{72}$ Беляев А.В. Международно-правовое регулирование Европейской валютной системы. М., 1998. С. 21.

${ }^{73}$ Шаповалов М.А. Международное финансовое право: предмет, система, источники // Финансовое право. 2010. № 3. С. 6-8.
} 
суть имущественные отношения. Они возникают в связи с передачей различного рода финансовых благ - валюты, ценных бумаг, производных финансовых инструментов, а также различных денежных прав требования, возникающих главным образом из кредитных договоров. Даже в отношениях с участием международных финансовых организаций, предоставляющих финансовые средства предприятиям из различных стран для целей развития, используются гражданско-правовые договоры. На международном финансовом рынке возникают имущественные отношения, то есть рыночные отношения, поэтому было бы неверным считать, что метод регулирования данных отношений не имеет значения. Напротив, в данных отношениях метод регулирования имеет первостепенное значение и этот метод - метод частного права: в первую очередь, - диспозитивный (автономия воли сторон) и во вторую - коллизионный и материально-правовой (международные соглашения и нормы национального законодательства).

Смешение отношений, имеющих различную правовую природу, не порождает ясности в их понимании. Так, предложенная Г.В. Петровой классификация международных финансовых отношений вызывает некоторую неопределенность в вопросе о том, что представляют собой международные финансовые отношения. При этом сложно определить единый критерий, которым руководствуется Г.В. Петрова. В одном случае критерием выступает основание возникновения правоотношения (генеральные соглашения, бессрочные и временные финансовые договоры, «договоры-законы» и «договоры-сделки», решения, рекомендации и принципы международных организаций), в другом - субъектный состав (международные организации в системе $\mathrm{OOH}$, кредитные организации на финансовых рынках), в третьем - цель (обеспечение гарантий исполнения). Очевидно, что отношения, возникающие на основе «договоров-законов», «договоров-сделок» и в результате «обеспечения гарантий исполнения» будут иметь различную правовую природу. Думается, что предложенная Г.В. Петровой классификация нуждается в существенной доработке.

Подобного смешения различных отношений можно избежать, используя подход, применяемый В.М. Шумиловым. Автор упоминает о двух категориях отношений, которые рассматриваются в контексте международной финансовой системы: во-первых, урегулированные нормами права имущественные отношения, складывающиеся по поводу финансо- вых благ и осложненные иностранным элементом (международные частные финансовые (валютные) отношения), и, во-вторых, межгосударственные отношения, складывающиеся по поводу трансграничного движения финансовых ресурсов, по поводу внутренних правовых режимов (международное финансовое право) $)^{74}$. Однако, признавая возможность различных точек зрения в отношении того, что представляют собой международные финансовые отношения, B.М. Шумилов, тем не менее, предлагает отнести международное финансовое право к отдельной отрасли международного экономического права, то есть к отрасли публичного права ${ }^{75}$. Следует отметить, что ряд авторов придерживается аналогичной позиции ${ }^{76}$.

Таким образом, в отечественной юридической литературе существует, по крайней мере, две точки зрения применительно к тому, что представляют собой международные финансовые правоотношения и право, регулирующее данные отношения. Одни авторы рассматривают данные понятия в комплексе, в то время как другие - лишь с позиций международного права. Следует признать, что в первом случае попытка включить в предмет изучения любого рода правоотношения помогает продемонстрировать разнообразие данных правоотношений, но не отражает их правовой природы и не может привести к практическим выводам. В другом случае попытка изучения лишь публично-правовых отношений и норм исключает имущественные отношения (или, используя терминологию, предложенную В.М. Шумиловым, «международные частные финансовые отношения»), составляющие ядро международного финансового рынка.

\footnotetext{
${ }^{74}$ Шумилов В.М. Международное финансовое право. М.: Международные отношения, 2005. С. 27.

75 Шумилов В.М. Международное финансовое право. М.: Международные отношения, 2005. С. 27.

${ }^{76}$ Вельяминов Г.М. Международное экономическое право и процесс. М.: Волтерс Клувер, 2004; Иванова Е.Е. Международное финансовое право: понятие, предмет, система // Международное публичное и частное право. 2004. № 16. С. 21; Международное право // под ред. Ю.М. Колосова, В.И. Кузнецова. М.: Международные отношения, 1999. С. 427; Кузнецов В.С. Международные валютно-финансовые организации стран капитализма. М.: МГИМО, 1980. С. 92; Международное право / под ред. Г.В. Игнатенко, О.И. Титова. М.: Норма, 1999. С. 450; Сафина О.А. Международноправовое регулирование кредитно-денежных и расчетных отношений на универсальном уровне: Автореф. ... канд. юрид. наук. М., 2005. С. 5; Шумилов Ю.В. Эволюция международного финансового права в свете глобального финансово-экономического кризиса 2008-2010 гг: Дисс. ... канд. юрид. наук. М., 2010.
} 
Для примера можно привести взгляды иностранных авторов. В зарубежной литературе обнаруживаются работы, посвященные, во-первых, вопросам «международного валютного права», рассматриваемого в рамках международного экономического права ${ }^{77}$. В предмет данной отрасли включаются такие вопросы, как история развития мировой валютной системы, системы финансовых организаций, финансовых кризисов и тому подобные. С другой стороны, зарубежные юристы посвящают свои труды вопросам «права международных финансов» ${ }^{78}$, рассматриваемого в качестве подотрасли международного частного права и включающего трансграничную деятельность, касающуюся платежных, кредитных инвестиционных или финансовых контрактов ${ }^{79}$. В свою очередь Ф. Вуд в предмет изучения включает вопросы правового регулирования синдицированного финансирования, кредитных сделок, выпуска международных облигаций, целевое финансирование, правовое регулирование уступки права требования, деривативов, секьюритизации, трастов, финансовое регулирование отдельных государств,

${ }^{77}$ Broncker M. Quick R. New Direction in International Economic Law: Essays in Honour of John H. Jackson. The Hague: Kluwer Law International, 2000; Fratianni M., Salvatore D., Savona P. Ideas for the Future of International Monetary System. Boston: Kluwer Academic Publishers, 1999; Qureshi A.H. Perspectives in International Economic Law. The Netherlands: Kluwer Law International, 2002; Seidl-Hohenveldern I. International Economic Law, The Netherlands: Kluwer Law International, 1999; Uzan M. The Future of the International Monetary System. Cheltenham: Edward Elgar Publs, 2005; Lowenfeld A. International Economic Law. Oxford: Oxford University Press, 2008; International Banking, Finance and Economic Law. The Hague: Kluwer law internantional, 2000. Vol. 14.

${ }^{78}$ McKnight A. The Law of International Finance. Oxford: Oxford University Press, 2008; Scott H.S. Op. cit.; International banking regulation and supervision: Change and transformation in the 1990s / Conf. on law and practice in international banking, 22-24 June 1992, Taipei, Taiwan ; Ed. by J.J. Norton et al. - London etc.: Graham \& Trotman: Nijhov, Cop. 1994; Hinterseer K. Studies in comparative corporate and financial law: SCFL. The Hague: Kluwer law intern., Cop. 2000, Vol. 15: Criminal finance: The political economy of money laundering in a comparative legal context. The Hague: Kluwer law international, Cop. 2002. - XCV, 496 c; Wood P.R. Conflicts of Law and International Finance. London: Thomson, Sweet and Maxwell, 2007; Wood P.R. Regulation in International Finance. London: Thomson, Sweet and Maxwell, 2007; Wood P.R. Predictions for the Future of Financial Law and Lawyers // Business Law International. 2008 Vol. 9. No. 3.

79 Такой позиции придерживается Э. МакНайт, Г. Дуфей и Дж. Чан. в том числе вопросы правовых коллизий в данных правоотношениях.

Таким образом, позиция отечественных правоведов отличается от позиции иностранных юристов. Следует сказать, что она еще не до конца сформировалась и в определенной степени унаследовала традиции советской правовой мысли, сохраняя публично-правовой уклон. Тем не менее, с учетом меняющихся экономических отношений, в том числе с учетом все большего участия российских предприятий в международных частных финансовых отношениях, сложившиеся позиции в отечественной доктрине требуют соответствующих корректировок.

Анализ вопросов, связанных с «правом международных финансов», можно обнаружить в работах отдельных отечественных юристов. В литературе есть работы, которые сфокусированы на избранных аспектах, связанных с международными частными финансовыми отношениями. Так, например, Л.А. Лунц детально исследовал денежные обязательства в гражданском и коллизионном праве капиталистических стран ${ }^{80}$. Он признавал, что вопросы денежных обязательств возникают также в сфере международного публичного права, однако предметом изучения Л.А. Лунцем были исключительно денежные обязательства в гражданском и коллизионном праве.

Предметом внимания большинства авторов в области международного частного права являются расчетные отношения ${ }^{81}$, трансграничные денежные обязательства ${ }^{82}$, международное вексельное и расчет-

\footnotetext{
${ }^{80}$ Луни Л.А. Деньги и денежные обязательства в гражданском праве. М.: Статут, 2004. С. 148-327. В своей монографии Л.А. Лунц отмечал, что «глубокое и внимательное изучение зарубежных правовых норм и вопросов международного частного права, касающихся денежных обязательств, вооружает наших юристов и экономистов необходимыми знаниями в деле защиты наших интересов в области внешней торговли и международных расчетов». Следует отметить, что в настоящее время данные знания понадобятся не только и не столько в сфере внешней торговли и международных расчетов, сколько в сфере международных финансовых рынков и международных финансовых инвестиций.

${ }^{81}$ Канашевский В.А. Международное частное право. М.: Международные отношения, 2009. С. 287-420. В.А. Канашевский упоминает также о страховании, но применительно к внешней торговле, экспортно-импортным операциям.

${ }^{82}$ Международное частное право / отв. ред. Г.К. Дмитриева. М.: Проспект, 2013. С. 356-389.
} 
ное право ${ }^{83}$, международные кредитные отношения ${ }^{84}$. И.В. Гетьман-Павлова выделяет международное частное валютное право, предметом которого являются «международные валютные отношения, складывающиеся при функционировании валюты в мировом хозяйстве» ${ }^{85}$.

\section{Сделки на международном финансовом рынке}

Как видно, в отечественной юридической литературе практически не предпринимались попытки комплексного изучения частных правоотношений на международных финансовых рынках. Работы отечественных авторов базируются в основном на международно-правовых нормах, регулирующих расчетные отношения, широко распространенные во внешнеторговых отношениях, и не отражают практику международных финансовых правоотношений, их особенности и сложную структуру.

Тем не менее, следует отметить работы А.В. Шамраева и Г.В. Петровой, посвященные данному вопросу. Отталкиваясь от того, что международное финансовое правоотношение - суть частное и порождается соответствующими трансграничной сделкой, необходимо вначале попытаться дать определение указанной сделки. А.В. Шамраев определяет международные финансовые сделки как «трансграничные сделки с участием в качестве как минимум одной из сторон сделки финансовой организации, обладающей специальной правоспособностью на осуществление банковской деятельности или деятельности на финансовом рынке» ${ }^{86}$. По мнению А.В. Шамраева,

${ }^{83}$ Eрпьлева Н.Ю. Международное частное право. М.: Издательство Юрайт, 2012. С. 881-1045. Предметом изучения Н.Ю. Ерпылевой являются также банковские гарантии. См.: Ерпылева Н.Ю. Международное банковское право. М.: Издательство НИУ «Высшая школа экономики», 2012.

84 Звеков В.П. Международное частное право. М.: Издательская группа НОРМА-ИНФРА М, 1999. С. 329-358.

${ }^{85}$ Гетьман-Павлова И.В. Международное частное право. М.: Эксмо, 2011. С. 325-356.

${ }^{86}$ Шамраев А.В. Указ. соч. С. 6. Таким образом, основными квалифицирующими признаками международных финансовых отношений А.В. Шамраев признает, во-первых, присутствие иностранного элемента и, во-вторых, специальный субъектный состав. Нельзя согласиться с мнением А.В. Шамраева о том, что субъектами международных финансовых отношений являются лица, обладающие специальной правоспособностью. Так, например, международные кредиты предоставляются обычным юридическим лицам, а инвесторами международных облигаций и акций могут выступать просто физические лица. трансграничность (под которой автор, по всей видимости, подразумевает присутствие иностранного элемента) может проявляться следующим образом:

- при нахождении сторон международной финансовой сделки в различных государствах (банк и клиент, банки при межбанковских сделках, участник финансового рынка и клиент, биржа и участники и т.д.);

- $\quad$ при нахождении в различных государствах финансовых организаций, входящих в синдикат (при синдицированном кредитовании, выпуске еврооблигаций и т.д.);

- при нахождении в различных государствах финансовой инфраструктуры и обслуживаемых финансовых организаций ${ }^{87}$. Таким образом, А.В. Шамраев определяет «трансграничность» данных отношений через субъектный состав: один из субъектов должен находиться на территории по крайней мере одного государства. Несколько иначе подходит к определению иностранного элемента Г.В. Петрова, которая придерживается следующего мнения: иностранный элемент может проявиться «либо в том, что субъектом такого отношения является иностранный или международный публичный субъект, иностранный гражданин, иностранное юридическое лицо; либо когда объектом международного финансового правоотношения являются, например, финансовые средства, находящиеся за границей; либо в том, что юридические факты, с которыми связаны возникновение, изменение или прекращение правоотношений, имеют место за границей (например, финансовая операция или правонарушение совершены за границей; обязательство подлежит исполнению за границей и др.)» ${ }^{88}$. Как видно, Г.В. Петрова становится на позиции международного частного права при определении иностранного элемента в международных финансовых отношениях.

Таким образом, можно выделить общие черты, присущие всем без исключения международным частным финансовым правоотношениям, - они порождаются трансграничными сделкам, то есть сделками, в которых присутствует иностранный элемент. Иностранный элемент может проявляться в субъектном составе, в объекте правоотношения, либо в юридическом факте, с которым связано возникновение, изменение или прекращение международного

\footnotetext{
${ }^{87}$ Там же. С. 6-7.

${ }^{88}$ Петрова Г.В. Указ. соч. С. 79.
} 
финансового правоотношения. Так, например, обязательство всякого договора международного займа будет выражено всегда в валюте, которая «по меньшей мере для одной из сторон соответственной сделки будет иностранною» ${ }^{89}$.

Иностранный элемент будет иметь свои особенности в зависимости от вида конкретного международного финансового правоотношения. К примеру, при выпуске еврооблигаций на стороне должника будет юридическое лицо, в то время как на стороне кредитора будет множественность лиц - инвесторов и, вполне вероятно, они будут находиться в различных государствах; права на еврооблигации, в свою очередь, будут учитываться на счетах у специализированного посредника; исполнение по облигациям может производиться на территории иностранного государства и т. д.

Международный финансовый рынок состоит из двух основных сегментов - денежного рынка и рынка капиталов. Денежный рынок - эта та часть международного финансового рынка, на котором заключаются сделки с краткосрочными финансовыми инструментами, такими как займы на срок до одного года, сделки репо с различными валютами, с производными финансовыми инструментами. На рынке капиталов торгуются капиталы, то есть денежные фонды (финансовые средства) значительных размеров.

К основным сделкам на международном рынке капитала относят трансграничный выпуск акций, международных облигаций и международные (синдицированные) кредитные договоры ${ }^{90}$. Следует отметить, что данные сделки - основные сделки, они порождают сложные правоотношения, а также служат стимулом к заключению других сделок и

\footnotetext{
${ }^{89}$ Луни Л.А. Указ. соч. С. 158. Тем не менее, по мнению Л.А. Лунца, это не будет служить основанием для применения иностранного права к соответствующим отношениям: «по всем правовым системам обязательство уплатить иностранную валюту (поскольку такое обязательство вообще допускается по закону) обсуждается по правилам, установленным для денежных обязательств». К таким обязательствам будут применяться, в частности, правила о процентах, о месте исполнения денежного обязательства и многие другие нормы, касающиеся вообще денежных обязательств.

${ }^{90}$ McKnight A. Op. cit. P. 95; Mugasha A. International Financial Law: Is the Law Really «International» and Is It «Law» Anyway? // Banking and Finance Law Review. 2011. P. 3; Wood P.R. Comparative law of security interests and title finance. Sweet \& Maxwell, 2007; Wood P.R. Law and Practice of International Finance. Sweet \& Maxwell, 2008; Delaume G.R. Legal Aspects of International Lending and Economic Development. Oceana Publications, Inc: Dobbs Ferry, New York, 1967.
}

соглашений - сделок по обеспечению, сделок, связанных с расчетами по данным обязательствам, сделок, связанных с представительством и других ${ }^{91}$.

У правоотношений, возникающих из международных займов и облигаций, есть много общего: они возникают на международном кредитном рынке, кредитором и должником в них выступают лица различной национальной принадлежности, а валюта обязательств в данных правоотношениях является иностранной, по крайней мере, в отношении одного из участников, как правило, заемщика. В предоставлении международного займа и выпуска облигаций задействованы одни и те же участники рынка: юридические лица, главным образом, крупные транснациональные предприятия, банки, инвестиционные компании, андеррайтеры, аудиторы и др. Кредит и облигация являются формами займа ${ }^{92}$. Подтверждением того, что кредиты и облигации определенным образом связаны, служит также тот факт, что в предпринятом в рамках УНИДРУА исследования, посвященном разработке унифицированных правил, применимых к международным займам, последние рассматривались в тесной связи с правами по облигациям ${ }^{93}$. Разработчики данного документа намеревались создать свод норм, регулирующие отношения по международным займам, аналогичный Гаагским правилам, разработанным применительно к морскому транспорту ${ }^{94}$.

Однако между правоотношениями, возникающими из международных займов и облигаций, есть и некоторые отличия: основанием возникновения международного частного кредитного правоотношения служат кредитные соглашения, а облигационных - проспекты эмиссии облигаций. Перемена лиц в правоотношениях

\footnotetext{
${ }^{91}$ Так, по мнению А.Я. Курбатова кредитование сопровождается целым комплексом сделок, связанных с внесением вкладов (депозитов), с возмездным приобретением денежных требований, с осуществлением выплат по банковским гарантиям или договорам поручительства и прочими. См.: Курбатов А.Я. Банковское и небанковское кредитование: понятие и критерии разграничения // СПС «Консультант Плюс».

${ }^{92}$ К примеру, в соответствии с положениями Гражданского кодекса РФ к отношениям по кредитному договору и облигациям применяются правила о займе, если иное не предусмотрено специальными нормами (п. 2 ст. 819, ст. 816).

${ }^{93}$ Unification of Law. International Institute of the Unification of Private Law. Rome, 1948. P. 41.

${ }^{94}$ League of Nations. Report of the Committee for Study of International Loan Contracts, C. 145. M. 93. 1939. II A., P. 25.
} 
из кредитных договоров и облигаций различна: передача прав по кредиту оформляется заключением дополнительных соглашений об уступке прав, в то время как для международных облигаций достаточно договора купли-продажи и обращения к депозитарию. С другой стороны, выпуск международных облигаций - это выпуск ценных бумаг. В этом отношении международные облигации имеют много общего с трансграничным размещением акций. Так, к примеру, на мировых финансовых рынках облигации вместе с акциями образуют единый рынок ценных бумаг. Облигации, как и акции, выпускаются путем эмиссии, и подчиняются аналогичным правилам обращения на вторичном рынке. Стоимость облигаций и акций зависит от аналогичных экономических показателей. Вместе с тем у акций и облигаций имеются существенные различия, прежде всего, с точки зрения права.

Во-первых, в отличие от акций облигации представляют собой форму кредитования: финансовые средства по облигациям передаются под процент и подлежат возврату по истечении срока. Акции, в свою очередь, являются инструментом участия в имуществе юридического лица и управления им, а средства возвращаются держателю только после ликвидации корпорации ${ }^{95}$. Во-вторых, хотя по форме облигации представляют собой ценные бумаги, будучи выраженными в иностранной валюте и выпущенными на международном финансовом рынке, они не подпадают под общие требования регистрации эмиссии, а торговля на вторичном рынке осуществляется вне мировых биржевых площадок (over-the-counter), следовательно, они выбывают из правового поля организованного рынка ценных бумаг. В свою очередь, выпуск и обращение акций подчиняется внутреннему законодательству той или иной страны. Таким образом, международные облигации - это в сущности международный заём, а по форме - ценная бумага ${ }^{96}$.

\footnotetext{
${ }^{95}$ Каманина Т.В. Корпоративное право. М.: Юрайт, 2010.

${ }^{96}$ Как отмечает Ф. Вуд, к основным отличиям между облигациями и кредитами относятся: 1) облигации могут свободно предлагаться к продаже (are easily marketable), в то время как банки обычно не торгуют кредитами; 2) кредиторами (инвесторами) по облигациям может быть огромное количество лиц, сохраняя свою анонимность; 3) условия выпуска облигаций более стандартизированы и просты; 4) на выпуск облигаций распространяются требования законодательства о ценных бумагах. См.: Philip R. Wood. International Loans, Bonds and Securities Regulation. London: Sweet\&Maxwell, 1995. P. 9.
}

Перечисленные выше характеристики правоотношений из международных займов и облигаций позволяют выявить следующие особенности их правового режима. Во-первых, возникающие правовые коллизии: поскольку данные правоотношения связаны с несколькими странами, непременно возникает конфликт между законами этих стран - коллизия, которую необходимо решить. Это особенно важно при выпуске глобальных облигаций: в этих случаях количество затронутых обязательством юрисдикций может достигать тридцати ${ }^{97}$. Как следствие, особую роль играет международное частное право и тщательная оценка всех рисков, связанных с выбором применимого права и сверх-императивными нормами затрагиваемых юрисдикций. Во-вторых, порядок разрешения споров: несмотря на то, что большинство споров рассматривается в рамках одной страны и одного суда, не исключено участие в процессе одновременно в нескольких странах. Например, если в отношении должника будет инициирована процедура несостоятельности, то кредиторам, скорее всего, придется защищать свои интересы в различных судах: обеспечивающее обязательства должника имущество может располагаться в различных государствах. Рассмотрение спора в одном суде практически невозможно потому, что в подавляющем количестве стран существуют жесткие правила в отношении исключительной юрисдикции судов, например, в отношении споров, связанных с недвижимостью. Во-третьих, вопросы, связанные с установление содержания права: из-за того, что международное частное право лишь отсылает к определенному правопорядку, оно не решает вопрос по существу. Следовательно, если защита прав в данных правоотношениях будет осуществляться в нескольких государствах, при том, что применимым правом будет лишь право одного из них, субъекты данных правоотношений будут вынуждены пояснять судам особо содержание права, применимого к возникшим между ними правоотношений, а вопрос представления доказательств по делу будет еще более усложнен.

\footnotetext{
${ }^{97}$ Wood P.R. Comparative financial law. London: Sweet\&Maxwell,
} 1995. P. 22. 


\section{Библиография:}

1. Бобов М.О. Новые требования к капиталу банков // Внутренний контроль в кредитной организации. 2012. № 4;

2. Arner D.W., Taylor M.W. The Global Financial Crisis and the Financial Stability Board: Hardening the Soft Law of International Financial Regulation? // University of New South Wales Law Journal. 2009. Vol. 32 (2). P. 488-513;

3. Karmel R.S., Kelly C.R. The Hardening of Soft Law in Securities Regulation // Brooklyn Journal of International Law. 2009. Vol. 34:3. P. 884-951;

4. Möllers T.M.J. Sources of Law in European Securities Regulation - Effective Regulation, Soft Law and Legal Taxonomy from Lamfalussy to de Larosière // European Business Organization Law Review. 2010. Vol. 11 P. 379-407.

5. Канашевский В.А. Внешнеэкономические сделки: материально-правовое и коллизионное регулирование. М.: Волтерс Клувер, 2010. С. 499-514.

6. Шумилов В.М. Международное финансовое право: понятие, предмет, система // Юрист-международник. 2005. № 1. C. 14.

7. Шамраев А.В. Правовое регулирование международных банковских сделок и сделок на международных финансовых рынках. М.: КНОРУС, ЦИПСиР, 2010. С. 7.

8. Нобель П. Швейцарское финансовое право и международные стандарты. М., Инфотропик Медиа, 2012. С. 116.

9. Баренбойм П.Д. Законопроект о реформе гражданского кодекса игнорирует интересы российских вкладчиков и мировой опыт антикризисной работы на финансовых рынках // Право и экономика. 2010. № 11;

10. Х Хорошилов С.Д. Банковский сектор стран - членов Совета по сотрудничеству в Персидском заливе // Международные банковские операции. 2006. № 4.

11. Mullineux A.W., Murinde V. Handbook of International Banking. Edward Elgar Publishing Limited, 2003. P. 10.

12. Гетьман-Павлова И.В. Коллизионное регулирование оборота ценных бумаг // Банковское право. 2007. № 5.

13. Ерпылева Н.Ю., Клевченкова М.Н. Коллизионное регулирование обращения ценных бумаг: частноправовые аспекты // Законодательство и экономика. 2009. № 6.

14. Выговский А. И. Бездокументарные ценные бумаги как объекты коллизионно-правового регулирования // Налоги. 2012. № 15

15. Black V. Foreign Currency Obligations in Private International Law. Hague Academy of International Law, 2004. P. 165-190.

16. Селивановский А. Рамочные договоры о срочных сделках (деривативах) // Рынок ценных бумаг. 2008. № 7. С. 15-17.

17. Дудин А.П. Диалектика правоотношения. Саратов: Издательство Саратовского университета, 1983. С.

18. Ерпылева Н.Ю., Максимов Д.М.. Унификация правового регулирования международных речных перевозок грузов, пассажиров и багажа // Право и политика. - 2013. - № 10. - C. 104-107. DOI: 10.7256/1811-9018.2013.10.9193.

19. Н.Ю. Ерпылева. Организационно-правовые формы трансграничного движения капитала в российской банковской системе // Право и политика. - 2013. - № 4. - C. 104-107. DOI: 10.7256/1811-9018.2013.04.9.

20. Н.Ю. Ерпылева, К.В. Филимонов. Ликвидация российских кредитных организаций (новеллы правового регулирования) // Право и политика. - 2012. - № 11. - С. 104-107.

21. Н. Ю. Ерпылева. Международный гражданский процесс: институционно-нормативный механизм правового регулирования // Право и политика. - 2012. - № 10. - С. 104-107.

22. Н. Ю. Ерпылева. Международный гражданский процесс: институционно-нормативный механизм правового регулирования // Право и политика. - 2012. - № 9. - С. 104-107.

23. Н. Ю. Ерпылева, М. Н. Клевченкова, Д. М. Максимов. Правовой режим функционирования торговых обществ во Франции // Право и политика. - 2012. - № 3. - С. 104-107.

24. Н.Ю. Ерпылева, И.В. Гетьман-Павлова. Трансграничное банкротство в международном частном праве // Право и политика. - 2009. - № 11 .

25. Анисимова 3.М.. Повышение эффективности стратегического банковского менеджмента в современных условиях // Тренды и управление. - 2013. - № 4. - C. 104-107. DOI: 10.7256/2307-9118.2013.4.10522.

26. А. А. Лукашев. Подотраслевая природа финансово-правовых норм, регулирующих бюджетные отношения // Финансовое право и управление. - 2013. - № 2. - С. 104-107. DOI: 10.7256/2310-0508.2013.2.9863.

27. Н.И. Химичева. Принципы современного российского финансового права как основы бюджетно-правового регулирования // Финансовое право и управление. - 2013. - № 2. - C. 104-107. DOI: 10.7256/2310-0508.2013.2.9860.

28. А.В. Левитский. Финансовый контроль в России в условиях вступления в ВТО // Финансовое право и управление. - 2013. - № 2. - C. 104-107. DOI: 10.7256/2310-0508.2013.2.9727.

29. О.В. Болтинова. К вопросу о государственном финансовом контроле в Российской Федерации // Финансовое право и управление. - 2013. - № 2. - С. 104-107. DOI: 10.7256/2310-0508.2013.2.9725.

30. Л.Л. Арзуманова. Финансовая политика государства: понятие и ее составные элементы // Финансовое право и управление. - 2013. - № 1. - C. 104-107. DOI: 10.7256/.2013.1.9525. 
31. Е.В. Соловова. Выпуск государственных и муниципальных ценных бумаг как способ привлечения заемных средств в США // Финансовое право и управление. - 2013. - № 1. - С. 104-107. DOI: 10.7256/.2013.1.9498.

32. Е.В. Бурцева. Основные подходы к совершенствованию методов оценки финансовой устойчивости промышленных предприятий в условиях нестабильности // Тренды и управление. - 2013. - № 1. - C. 104-107. DOI: 10.7256/2307-9118.2013.01.9.

33. П.В. Павлов. Офшорные зоны в России и за рубежом: экономико-правовые основы функционирования // Тренды и управление. - 2013. - № 1. - С. 104-107. DOI: 10.7256/2307-9118.2013.01.7.

34. Д.А. Чугунов. Особенности и законодательные проблемы регулирования сделок секъютеризации страховых активов в России // Налоги и налогообложение. - 2013. - № 3. - C. 104-107. DOI: 10.7256/1812-8688.2013.03.2.

35. К.Д. Аллабян. Государственное регулирование процессов реорганизации страхового бизнеса в Российской Федерации // Право и политика. - 2012. - № 12. - С. 104-107.

36. М.Л. Синицына. Антикризисные меры ЕС. Анализ современных финансовых реформ // Налоги и налогообложение. - 2012. - № 8. - С. 104-107.

37. А.С. Галяутдинова. Коллективный субъект финансового права: происхождение термина и содержание понятие // Налоги и налогообложение. - 2012. - № 7. - С. 104-107.

38. А. И. Некрасов. Принципы правового регулирования политики Европейского Союзав области финансовых услуг // Международное право и международные организации / International Law and International Organizations. - 2011. - № 3. - С. 104-107

39. М. В. Михайлов Банковская система как специфический объект правового регулирования в условиях финансового кризиса // Право и политика. - 2012. - 4. - С. 717 - 725.

\section{References (transliterated):}

1. Bobov M.O. Novye trebovaniya k kapitalu bankov // Vnutrennii kontrol’ v kreditnoi organizatsii. 2012. № 4;

2. Arner D.W., Taylor M.W. The Global Financial Crisis and the Financial Stability Board: Hardening the Soft Law of International Financial Regulation? // University of New South Wales Law Journal. 2009. Vol. 32 (2). P. 488-513;

3. Karmel R.S., Kelly C.R. The Hardening of Soft Law in Securities Regulation // Brooklyn Journal of International Law. 2009. Vol. 34:3. P. 884-951;

4. Möllers T.M.J. Sources of Law in European Securities Regulation - Effective Regulation, Soft Law and Legal Taxonomy from Lamfalussy to de Larosière // European Business Organization Law Review. 2010. Vol. 11 P. $379-407$.

5. Kanashevskii V.A. Vneshneekonomicheskie sdelki: material'no-pravovoe i kollizionnoe regulirovanie. M.: Volters Kluver, 2010. S. 499-514.

6. Shumilov V.M. Mezhdunarodnoe finansovoe pravo: ponyatie, predmet, sistema // Yurist-mezhdunarodnik. 2005 . № 1. S. 14.

7. Shamraev A.V. Pravovoe regulirovanie mezhdunarodnykh bankovskikh sdelok i sdelok na mezhdunarodnykh finansovykh rynkakh. M.: KNORUS, TsIPSiR, 2010. S. 7.

8. Nobel' P. Shveitsarskoe finansovoe pravo i mezhdunarodnye standarty. M., Infotropik Media, 2012. S. 116.

9. Barenboim P.D. Zakonoproekt o reforme grazhdanskogo kodeksa ignoriruet interesy rossiiskikh vkladchikov i mirovoi opyt antikrizisnoi raboty na finansovykh rynkakh // Pravo i ekonomika. 2010. № 11;

10. Khoroshilov S.D. Bankovskii sektor stran - chlenov Soveta po sotrudnichestvu v Persidskom zalive // Mezhdunarodnye bankovskie operatsii. 2006. № 4.

11. Mullineux A.W., Murinde V. Handbook of International Banking. Edward Elgar Publishing Limited, 2003. P. 10.

12. Get’man-Pavlova I.V. Kollizionnoe regulirovanie oborota tsennykh bumag // Bankovskoe pravo. 2007 . № 5.

13. Erpyleva N.Yu., Klevchenkova M.N. Kollizionnoe regulirovanie obrashcheniya tsennykh bumag: chastnopravovye aspekty // Zakonodatel'stvo i ekonomika. 2009. № 6.

14. Vygovskii A. I. Bezdokumentarnye tsennye bumagi kak ob’ekty kollizionno-pravovogo regulirovaniya // Nalogi. 2012 . № 15

15. Black V. Foreign Currency Obligations in Private International Law. Hague Academy of International Law, 2004. P. 165-190.

16. Selivanovskii A. Ramochnye dogovory o srochnykh sdelkakh (derivativakh) // Rynok tsennykh bumag. 2008. № 7. S. 15-17.

17. Dudin A.P. Dialektika pravootnosheniya. Saratov: Izdatel'stvo Saratovskogo universiteta, 1983. S.

18. Erpyleva N.Yu., Maksimov D.M.. Unifikatsiya pravovogo regulirovaniya mezhdunarodnykh rechnykh perevozok gruzov, passazhirov i bagazha // Pravo i politika. - 2013. - № 10. - S. 104-107. DOI: 10.7256/1811-9018.2013.10.9193.

19. N.Yu. Erpyleva. Organizatsionno-pravovye formy transgranichnogo dvizheniya kapitala v rossiiskoi bankovskoi sisteme // Pravo i politika. - 2013. - № 4. - S. 104-107. DOI: 10.7256/1811-9018.2013.04.9.

20. N.Yu. Erpyleva, K.V. Filimonov. Likvidatsiya rossiiskikh kreditnykh organizatsii (novelly pravovogo regulirovaniya) // Pravo i politika. - 2012. - № 11. - S. 104-107. 
DOI: $10.7256 / 2226-6305.2014 .3 .11572$

При цитировании этой статьи сноска на doі обязательна

Международное право и международные организации•з•2014 International Law and International Organizations

21. N. Yu. Erpyleva. Mezhdunarodnyi grazhdanskii protsess: institutsionno-normativnyi mekhanizm pravovogo regulirovaniya // Pravo i politika. - 2012. - № 10. - S. 104-107.

22. N. Yu. Erpyleva. Mezhdunarodnyi grazhdanskii protsess: institutsionno-normativnyi mekhanizm pravovogo regulirovaniya // Pravo i politika. - 2012. - № 9. - S. 104-107.

23. N. Yu. Erpyleva, M. N. Klevchenkova, D. M. Maksimov. Pravovoi rezhim funktsionirovaniya torgovykh obshchestv vo Frantsii // Pravo i politika. - 2012. - № 3. - S. 104-107.

24. N.Yu. Erpyleva, I.V. Get'man-Pavlova. Transgranichnoe bankrotstvo v mezhdunarodnom chastnom prave // Pravo i politika. - 2009. - № 11.

25. Anisimova Z.M.. Povyshenie effektivnosti strategicheskogo bankovskogo menedzhmenta v sovremennykh usloviyakh // Trendy i upravlenie. - 2013. - № 4. - S. 104-107. DOI: 10.7256/2307-9118.2013.4.10522.

26. A. A. Lukashev. Podotraslevaya priroda finansovo-pravovykh norm, reguliruyushchikh byudzhetnye otnosheniya // Finansovoe pravo i upravlenie. - 2013. - № 2. - S. 104-107. DOI: 10.7256/2310-0508.2013.2.9863.

27. N.I. Khimicheva. Printsipy sovremennogo rossiiskogo finansovogo prava kak osnovy byudzhetno-pravovogo regulirovaniya // Finansovoe pravo i upravlenie. - 2013. - № 2. - S. 104-107. DOI: 10.7256/2310-0508.2013.2.9860.

28. A.V. Levitskii. Finansovyi kontrol' v Rossii v usloviyakh vstupleniya v VTO // Finansovoe pravo i upravlenie. - 2013. № 2. - S. 104-107. DOI: 10.7256/2310-0508.2013.2.9727.

29. O.V. Boltinova. K voprosu o gosudarstvennom finansovom kontrole v Rossiiskoi Federatsii // Finansovoe pravo i upravlenie. - 2013. - № 2. - S. 104-107. DOI: 10.7256/2310-0508.2013.2.9725.

30. L.L. Arzumanova. Finansovaya politika gosudarstva: ponyatie i ee sostavnye elementy // Finansovoe pravo i upravlenie. 2013. - № 1. - S. 104-107. DOI: 10.7256/.2013.1.9525.

31. E.V. Solovova. Vypusk gosudarstvennykh i munitsipal'nykh tsennykh bumag kak sposob privlecheniya zaemnykh sredstv v SShA // Finansovoe pravo i upravlenie. - 2013. - № 1. - S. 104-107. DOI: 10.7256/.2013.1.9498.

32. E.V. Burtseva. Osnovnye podkhody k sovershenstvovaniyu metodov otsenki finansovoi ustoichivosti promyshlennykh predpriyatii v usloviyakh nestabil'nosti // Trendy i upravlenie. - 2013. - № 1. - S. 104-107. DOI: 10.7256/2307-9118.2013.01.9.

33. P.V. Pavlov. Ofshornye zony v Rossii i za rubezhom: ekonomiko-pravovye osnovy funktsionirovaniya // Trendy i upravlenie. - 2013. - № 1. - S. 104-107. DOI: 10.7256/2307-9118.2013.01.7.

34. D.A. Chugunov. Osobennosti i zakonodatel'nye problemy regulirovaniya sdelok sek"yuterizatsii strakhovykh aktivov v Rossii // Nalogi i nalogooblozhenie. - 2013. - № 3. - S. 104-107. DOI: 10.7256/1812-8688.2013.03.2.

35. K.D. Allabyan. Gosudarstvennoe regulirovanie protsessov reorganizatsii strakhovogo biznesa v Rossiiskoi Federatsii // Pravo i politika. - 2012. - № 12. - S. 104-107.

36. M.L. Sinitsyna. Antikrizisnye mery ES. Analiz sovremennykh finansovykh reform // Nalogi i nalogooblozhenie. -2012. - № 8. - S. 104-107.

37. A.S. Galyautdinova. Kollektivnyi sub"ekt finansovogo prava: proiskhozhdenie termina i soderzhanie ponyatie // Nalogi i nalogooblozhenie. - 2012. - № 7. - S. 104-107.

38. A. I. Nekrasov. Printsipy pravovogo regulirovaniya politiki Evropeiskogo Soyuzav oblasti finansovykh uslug // Mezhdunarodnoe pravo i mezhdunarodnye organizatsii / International Law and International Organizations. - 2011. - № 3. - S. 104-107

39. M. V. Mikhailov Bankovskaya sistema kak spetsificheskii ob"ekt pravovogo regulirovaniya v usloviyakh finansovogo krizisa // Pravo i politika. - 2012. - 4. - C. $717-725$. 